\title{
A multi-methodological study of kernite, a mineral commodity of boron
}

G. Diego Gatta, Alessandro Guastoni, Paolo Lotti, Giorgio Guastella, Oscar Fabelo and Maria Teresa Fernandez-Diaz

Running title: Crystal chemistry of kernite

\begin{abstract}
Keywords
Introduction
\end{abstract}

Sample description and occurrence

Experimental methods and Results

1) Titrimetric determination of the boron content

2) Gravimetric method to determine the sodium content

3) Determination of fluorine content

4) Determination of $\mathrm{H}_{2} \mathrm{O}$ content by heating

5) Determination of minor elements by inductively coupled plasma atomic emission spectroscopy (ICP-AES)

5.1) Determination of REE concentration by ICP-AES

5.2) Determination of other minor elements concentration by ICP-AES

6) Determination of $\mathbf{C}, \mathbf{N}$, and $\mathbf{H}$

7) Single-crystal $X$-ray and neutron diffraction

7.1) $X$-ray and neutron data collections and treatments

7.2) $X$-ray and neutron structure refinements

Discussion and Implications

Acknowledgements

References

Figures/Tables

Corresponding author: G. Diego GATTA

Dipartimento di Scienze della Terra, Università degli Studi di Milano

Via Botticelli 23, I-20133 Milano, Italy

Tel.+3902 503 15607, Fax +3902 503 15597, E-Mail: diego.gatta@unimi.it

Manuscript submitted to American Mineralogist 


\title{
A multi-methodological study of kernite, a mineral commodity of boron
}

\author{
G. Diego Gatta ${ }^{1}$, Alessandro Guastoni ${ }^{2}$, Paolo Lotti ${ }^{1}$, Giorgio Guastella ${ }^{3}$, \\ Oscar Fabelo ${ }^{4}$ and Maria Teresa Fernandez-Diaz \\ ${ }^{1}$ Dipartimento di Scienze della Terra, Università degli Studi di Milano, \\ Via Botticelli 23, I-20133 Milano, Italy \\ ${ }^{2}$ Dipartmento di Geoscienze, Università degli Studi di Padova, \\ Via G. Gradenigo 6, I-35131, Padova, Italy \\ ${ }^{3}$ Agenzia delle Dogane e dei Monopoli, Direzione Regionale per la Lombardia, \\ Ufficio Antifrode - Sezione Laboratorio, Via Marco Bruto 14, I-20138 Milan, Italy \\ ${ }^{4}$ Institut Laue-Langevin, 71 Avenue des Martyrs, F-38000 Grenoble, France
}

\section{Abstract}

Kernite, ideally $\mathrm{Na}_{2} \mathrm{~B}_{4} \mathrm{O}_{6}(\mathrm{OH})_{2} \cdot 3 \mathrm{H}_{2} \mathrm{O}$, is one of the major constituent of the borate deposits and one of the most important mineral commodity of $\mathrm{B}$. The chemical composition and the crystal structure of kernite from the Kramer Deposit (Kern County, California) were investigated by a series of analytical techniques (i.e., titrimetric determination of $\mathrm{B}$ content, gravimetric method for $\mathrm{Na}$, ion selective electrode for $\mathrm{F}$, high- $\mathrm{T}$ mass loss for $\mathrm{H}_{2} \mathrm{O}$ content, inductively coupled plasma atomic emission spectroscopy for REE and other minor elements, elemental analysis for $\mathrm{C}, \mathrm{N}$ and $\mathrm{H}$ content) and by single-crystal X-ray (at $293 \mathrm{~K}$ ) and neutron (at $20 \mathrm{~K}$ ) diffraction. The concentration of more than 50 elements was measured. The general experimental formula of the kernite sample used in this study is: $\mathrm{Na}_{1.99} \mathrm{~B}_{3.99} \mathrm{O}_{6}(\mathrm{OH})_{2} \cdot 3 \cdot 01 \mathrm{H}_{2} \mathrm{O}$. The fraction of other elements is, overall, insignificant: excluding $\mathrm{B}$, kernite from the Kramer Deposit does not act as geochemical trap of other technologically-relevant elements (e.g., Li, Be or REE). The X-ray and neutron structure model obtained in this study confirm that the structure of kernite is built up by: two (crystallographically independent) triangular $\mathrm{BO}_{2} \mathrm{OH}$ groups and two tetrahedral $\mathrm{BO}_{4}$ groups, which share corner-bridging $\mathrm{O}$ atoms to form 3-fold rings, giving chains running along [010], and $\mathrm{NaO}_{4}(\mathrm{OH})\left(\mathrm{OH}_{2}\right)$ and $\mathrm{NaO}_{2}(\mathrm{OH})\left(\mathrm{OH}_{2}\right)_{3}$ polyhedra. Positional disorder of two $\mathrm{H}$ sites of $\mathrm{H}_{2} \mathrm{O}$ molecules was observed by the neutron structure refinement and corroborated by the maximum-entropy method calculation, which consistently provided a model based on a static disorder, rather than a dynamic one. The H-bonding network in the structure of kernite is complex, pervasive and play a primary role on its structural stability: the majority of the oxygen sites are involved in H-bonding, as donors or as acceptors. The potential utilizations of kernite, as source of $\mathrm{B}\left(\mathrm{B}_{2} \mathrm{O}_{3} \sim 50 \mathrm{wt} \%\right)$, are discussed, on the basis of the experimental findings of this study. 
Keywords: Kernite, borates, mineral commodity, X-ray diffraction, neutron diffraction, crystal chemistry, hydrogen bonding.

\section{Introduction}

Kernite is a hydrous borate with ideal chemical formula $\mathrm{Na}_{2} \mathrm{~B}_{4} \mathrm{O}_{6}(\mathrm{OH})_{2} \cdot 3 \mathrm{H}_{2} \mathrm{O}$. It is a constituent of sedimentary borate deposits, of which the more common minerals are borax (ideally $\mathrm{Na}_{2}\left[\mathrm{~B}_{4} \mathrm{O}_{5}(\mathrm{OH})_{4}\right] \cdot 8 \mathrm{H}_{2} \mathrm{O}$ ), ulexite (ideally $\mathrm{NaCa}\left[\mathrm{B}_{5} \mathrm{O}_{6}(\mathrm{OH})_{6}\right] \cdot 5 \mathrm{H}_{2} \mathrm{O}$ ), colemanite (ideally $\left.\mathrm{Ca}\left[\mathrm{B}_{3} \mathrm{O}_{4}(\mathrm{OH})_{3}\right] \cdot \mathrm{H}_{2} \mathrm{O}\right)$, kernite and tincalconite (ideally $\mathrm{Na}_{6}\left[\mathrm{~B}_{4} \mathrm{O}_{5}(\mathrm{OH})_{4}\right]_{3} \cdot 8 \mathrm{H}_{2} \mathrm{O}$ ). Ulexite, colemanite, kernite, and tincalconite account for more than $90 \%$ of the borate minerals used by industry worldwide (USGS 2019).

There is a raising interest to the light elements, in particular $\mathrm{Li}, \mathrm{B}$ and $\mathrm{Be}$, as technologically and industrially relevant: they are currently considered as "critical elements" (or "critical raw materials", according to the European Commission 2017), on the basis of their high economic importance and high supply risk. Natural borates represent the most important source of boron. In 1998, the world production on borates accounted for about 3.1 millions of tons; in 2009 the production increased to 4.5 Mtons and in 2017 to 9.8 Mtons (USGS 2018, and previous reports). Only a few mineral commodities (and among those $\mathrm{Li}$ ) experienced such a trend of production and consumption over the last decades. The principal reason of this raise is ascribed to the fact that boron is a strategic element for a series of technologically relevant processes and products: e.g., to produce heat-resistant glasses and ceramics, for the production of boron-treated low-alloy steels (in which B is used to influence the hardenability and the behaviour of the alloys at high temperature), for the production of radiation-shielding materials (due by the elevated ability of ${ }^{10} \mathrm{~B}$ to absorb thermal neutrons), as a critical micronutrient to the growth and health of plants or as insecticide, as an effective photothermocatalyst for the conversion of carbon dioxide. Among the aforementioned utilizations, one is referred to radiation emitted by nuclear reactors for energy production, scientific research activities or medical applications (i.e., boron neutron capture therapy $\mathrm{BNCT}$ ), and it is the only one in which the isotopic signature of $\mathrm{B}$ plays an important role: ${ }^{10} \mathrm{~B}$ shows a high capacity to absorb thermal neutrons due to its high cross section for the ${ }^{10} \mathrm{~B}(\mathrm{n}, \alpha)^{7} \mathrm{Li}$ reaction $(\sim 3840$ barns; Carter et al. 1953, Sears 1986, Palmer and Swihart 1996, Rauch and Waschkowski 2002), whereas that of ${ }^{11} \mathrm{~B}$ is almost irrelevant ( $~ 0.006$ barns). About $20 \%$ of natural boron occurs as ${ }^{10} \mathrm{~B}$.

In the framework of a long-term project to select potential B-bearing aggregates, we have recently investigated the crystal chemistry and the stability at non-ambient conditions (at high and low temperature, high pressure) of colemanite (Lotti et al. 2017, 2018, 2019) and kurnakovite (ideally 
$\mathrm{Mg}\left[\mathrm{B}_{3} \mathrm{O}_{3}(\mathrm{OH})_{5}\right] \cdot 5 \mathrm{H}_{2} \mathrm{O}$, Gatta et al. 2019a) using a multi-methodological approach. We now extend our crystal-chemical investigation to kernite, considering its availability in nature and the high $\mathrm{B}_{2} \mathrm{O}_{3}$ content ( $\sim 8 \mathrm{wt} \%$ ); this study will be followed by experiments on its $P-T$ behaviour and chemical stability.

Only a few studies were so far dedicated to kernite. The first important description of this mineral is ascribed to Schaller (1927), who provided optical parameters and a chemical wet analysis. Its crystal structure was first reported by Amoros (1945) using X-ray diffraction techniques, and later reinvestigated by Giese (1966), Cialdi et al. (1967), and Cooper et al. (1973). The X-ray structure refinement of Cooper et al. (1973) is the last one reported in the open literature. Kernite crystallizes in the monoclinic $P 21 / C$ space group, with $a \cong 7.02 \AA, b \cong 9.15 \AA, c \cong 15.68 \AA$, and $\beta \cong 108.9^{\circ}(\mathrm{Z}=4)$. As observed in other borates (e.g., colemanite, kurnakovite), even kernite contains both triangular planar $\mathrm{BO}_{2} \mathrm{OH}-$ and tetrahedral $\mathrm{BO}_{4}$-groups (Fig. 1). Two independent $\mathrm{Na}$ sites are sixfold-coordinated by $\mathrm{O}$ atoms, $\mathrm{OH}$ groups and $\mathrm{H}_{2} \mathrm{O}$ molecules. One triangular $\mathrm{BO}_{2} \mathrm{OH}$ group and two tetrahedral $\mathrm{BO}_{4}$ groups share cornerbridging $\mathrm{O}$ atoms to form 3 -fold rings (3B: $\Delta+2 \mathrm{~T}$ or $3 \mathrm{~B}:<\Delta 2[]>$, according to the Heller 1996 and Grice et al. 1999 notation), giving chains running along [010] and held together by hydrogen bonding (Fig. 1). FT-IR and Raman spectra of kernite were reported and interpreted by Jun et al. (1995) and Kloprogge and Frost (1999), and its high-pressure behaviour was later described by Silva et al. (2018) on the basis of in situ IR and Raman spectra evolution collected in a diamond-anvil cell. Even the T-induced dehydration behaviour (in vacuum and in air) of a natural kernite was reported by Sennova et al. (2005), on the basis of thermo-gravimetric analysis and X-ray powder diffraction data. However, no structural data (at room or at non-ambient conditions) are reported in the manuscripts of Jun et al. (1995), Kloprogge and Frost (1999), Sennova et al. (2005) and Silva et al. (2018).

Despite the general structure model reported by Cooper et al. (1973) appears to be consistent (in terms of bond distances and angles), their structure refinement provides only a partial view of the H-bonding configuration, due to the limitation of the X-ray diffraction at that time. For example, some of the H sites were described with isotropic displacement parameters up to six times larger (in $\AA^{2}$ ) than others, which could reflect a positional (static or dynamic) disorder. The occurrence of hydroxyl groups and cationcoordinated $\mathrm{H}_{2} \mathrm{O}$, which account for a total $\mathrm{H}_{2} \mathrm{O}$ content of about $26 \mathrm{wt} \%$, generates the need for a structure model with an accurate location of the H-sites. In addition, the very few chemical analyses of kernite available in the open literature reported only the major constituents, and are based on analytical protocols of the last century (Schaller 1927, Cipriani 1958, Hurlbut et al. 1973).

In this light, the aim of the present study is a reinvestigation of the crystal chemistry of kernite from the Kramer Deposit (California), by single-crystal X-ray (at room conditions) and neutron diffraction (at low temperature: $20 \mathrm{~K}$ ) along with a series of other analytical techniques aimed to fully characterise 
the chemical composition of the sample (i.e., titrimetric determination of B content, gravimetric method for $\mathrm{Na}$, ion selective electrode for $\mathrm{F}$, high- $\mathrm{T}$ mass loss for $\mathrm{H}_{2} \mathrm{O}$ content, inductively coupled plasma atomic emission spectroscopy - ICP-AES - for REE and other minor elements, elemental analysis for $\mathrm{C}, \mathrm{N}$ and $\mathrm{H}$ content). With this multi-methodological approach, we can provide: a description of the chemical composition of kernite in terms of major and minor components, with a particular attention to the potential B- and Na-substituents; an unambiguous location of all the proton sites and their vibrational regime, along with a picture of the complex H-bonding network; a description of B-coordination environment (e.g., aplanarity of the triangular $\mathrm{BO}_{2}(\mathrm{OH})$-group, polyhedral distortion of the tetrahedral $\mathrm{BO}_{2}(\mathrm{OH})_{2}$-groups).

The experimental findings of this study will be pivotal to fully understand if kernite can act as a carrier of other technologically-relevant elements (e.g., Li, Be, REE), its conditions of formation and occurrence, its behaviour at non-ambient $P-T$ conditions and the chemical reactivity, as its structure stability appears to be substantially governed by the H-bonding network.

\section{Sample description and occurrence}

The sample of kernite used in this study belongs to the collection of the Museum of Mineralogy of the University of Padova, Italy. The hand specimen is a colorless to white, glassy fragment of a large centimetric crystal elongated parallel to the $c$ axis and bounded by alternating cleavage faces, nearly perfect, of the basal pinacoid $c\{001\}$ and the prism $a\{100\}$.

The specimen was collected at the Kramer Deposit, Mohave desert, Kern County, California. Over 80 minerals were reported occurring in this deposit including a number of borates: borax, colemanite, greigite, hydroboracite, inderite, inyoite, kernite, kurnakovite, meyerhofferite, probertite, searlesite, tincalconite, tunellite and ulexite (Noble 1926, Schaller 1930, Morgan and Erd, 1969, Puffer 1975). The Kramer deposit consists of a lenticular mass of kernite, borax and lower fraction of colemanite and ulexite, measuring $1.6 \mathrm{~km}$ long, $0.8 \mathrm{~km}$ wide and up to $100 \mathrm{~m}$ thick. The borate minerals, several hundred feet underground, occur in a complex clay series, underlain by igneous rock composed by basaltic lavas, upper Miocenic in age and overlain by a stratigraphic series of continental arkosic sands (Obert and Long 1962, Siefke 1991). For tens of meter deep, kernite is the only borate observed in the deposit and it is the dominant mineral, so that the clay matrix is almost negligible in amount (Schaller 1930). The mode of occurrence shows the deposit was originally composed only of borax at the floor of a saline lake. Kernite increases abundance with depth, indicating that dehydration of borax increases as a result of depth and pressure. Borax dehydration to kernite occurs under natural conditions. When borax is exposed to open air, it alters to tincalconite, whilst kernite alteration to 
tincalconite occurs only partially and very slowly. The abundance of kernite in the lower part of the Kramer deposit suggests the temperature-pressure conditions from the borax-to-kernite reaction occurs in the range $50-60{ }^{\circ} \mathrm{C}$ and about 750 meters deep (Christ and Garrels 1959).

\section{Experimental methods and Results}

\section{1) Titrimetric determination of the boron content}

A mass of 80-100 mg of kernite was placed in a $50 \mathrm{ml}$ plastic test tube, along with $5 \mathrm{ml}$ of water and $3 \mathrm{ml}$ of hydrochloric acid $1 \mathrm{M}$. The plastic test tube was covered and transferred in an ultrasound bath for 1-2 hours. The resulting clear solution was transferred in a $300 \mathrm{ml}$ beaker, with water up to about $100 \mathrm{ml}$ of the total solution. A combined glass electrode (produced by $\mathrm{InLab}{ }^{\circledR}$ Routine Pro - Mettler Toledo) was immersed in the solution, and the $\mathrm{pH}$ was adjusted to 5.5-6.5 with solutions of $\mathrm{HCl}$ 0.1-1M and $\mathrm{NaOH}$ 0.1-1M. A mass of 5-6 grams of mannitol was added and stirred, until the complete dissolution of the solid phase. The solution was then titrated with $\mathrm{NaOH} 0.1 \mathrm{M}$ up to $\mathrm{pH}$ 8.3-8.7. The content of acid titrated was completely due to the presence of boric acid in solution, as the sample does not contain elements capable to hydrolyze the medium, or in general able to influence its acidity. The measured fraction of $\mathrm{B}_{2} \mathrm{O}_{3}$ was $50.9(2) \mathrm{wt} \%$.

\section{2) Gravimetric method to determine the sodium content}

A mass of 500-600 mg of kernite was placed in a weighed platinum crucible $\left(\mathrm{m}_{1}\right)$, acidified with $20 \mathrm{ml}$ of hydrochloric acid 1:1 and evaporated to dryness. Residue was treated with $25 \mathrm{ml}$ of methyl alcohol and $10 \mathrm{ml}$ of concentrated hydrochloric acid, and evaporated to dryness. The latter operation was repeated 4-5 times. Residue, in absence of other elements at a significant level (see other analyses) is pure $\mathrm{NaCl}$. Platinum crucible was dried in an oven at $110-130^{\circ} \mathrm{C}$ for $1-2 \mathrm{~h}$, cooled in a desiccator and weighed $\left(\mathrm{m}_{2}\right)$. The different of weigh $\left(\mathrm{m}_{2}-\mathrm{m}_{1}\right)$ is the Na content in the mineral, expressed as $\mathrm{NaCl}$. The measured fraction of $\mathrm{Na}_{2} \mathrm{O}$ was $22.6(2) \mathrm{wt} \%$.

\section{3) Determination of fluorine content}

A mineral sample of $20 \mathrm{mg}$ in mass was placed in a $50 \mathrm{ml}$ plastic test tube, along with $5 \mathrm{ml}$ of water and $3 \mathrm{ml}$ of hydrochloric acid $1 \mathrm{M}$. The plastic test tube was covered and transferred in an ultrasound bath for 1-2 hours. A volume of 2-3 $\mathrm{ml}$ of Total Ionic Strength Adjustment Buffer (Commercial solution TISAB III) was added to the clear solution and diluted to $20 \mathrm{ml}$ with water. 
The F content then was then determined using the perfectION ${ }^{\mathrm{TM}}$ Combination Fluoride Ion Selective Electrode (Mettler Toledo), adopting the conventional method of standard addition. Solutions of fluorine from 0.1 to $5.0 \mathrm{mg} / 1$ were prepared by Certified Reference Material - CRM $1000 \mathrm{mg} / 1 \mathrm{of}$ fluorine. The resulting $\mathrm{F}$ fraction was $0.01 \mathrm{wt} \%$ (uncertainty not determined).

\section{4) Determination of $\mathrm{H}_{2} \mathrm{O}$ content by heating}

A mass of 500-600 mg of sample was placed in a quartz crucible with lid, and gradually heated in a muffle furnace from $20^{\circ} \mathrm{C}$ up to $800^{\circ} \mathrm{C}$. Assuming that the mass loss represents the total amount of $\mathrm{H}_{2} \mathrm{O}$, the estimated $\mathrm{H}_{2} \mathrm{O}$ fraction of the kernite sample was $26.4(2) \mathrm{wt} \%$.

5) Determination of minor elements by inductively coupled plasma atomic emission spectroscopy (ICP-AES)

All determinations were performed in axial view mode for REE, and radial view mode for the other minor elements, with a Perkin Elmer Optima 7000DV ICP-AES spectrometer.

\section{1) Determination of REE concentration by ICP-AES}

A mass of $50 \mathrm{mg}$ of kernite sample was placed in a $50 \mathrm{ml}$ plastic test tube, along with $5 \mathrm{ml}$ of water and $3 \mathrm{ml}$ of hydrochloric acid $1 \mathrm{M}$. The plastic test tube was covered and transferred in an ultrasound bath for 1-2 hours. The resulting clear solution was then transferred in a $50 \mathrm{ml}$ volumetric flask and diluted with water. A calibration protocol was performed with a blank solution and a series of solutions prepared with: similar fractions of sodium and boron as those of the sample under investigation and REE concentration from 0.001 to $0.050 \mathrm{mg} / 1$ for each element (using CRM multi elemental standard mix for ICP). Results and instrumental parameters are listed in Table 1.

\section{2) Determination of other minor elements concentration by ICP-AES}

The determination of the non-REE minor elements was performed using two different protocols, described below:

i) A mass of 10-20 mg of kernite sample was placed in a $50 \mathrm{ml}$ plastic test tube, along with $5 \mathrm{ml}$ of water and $3 \mathrm{ml}$ of hydrochloric acid $1 \mathrm{M}$. The plastic test tube was covered and transferred in an ultrasound bath for 1-2 hours. The resulting clear solution was then transferred and diluted with water in a $25 \mathrm{ml}$ volumetric flask, containing $2.5 \mathrm{ml}$ of scandium solution $(100 \mathrm{mg} / \mathrm{l})$ as internal standard. A calibration protocol was adopted with a blank solution and a series of 5 solutions prepared with concentration 
between 0.05 and $1.0 \mathrm{mg} / 1$ for each element (using CRM multi elemental standard mix for ICP).

ii) Decomposition by alkaline fusion of 10-20 $\mathrm{mg}$ of kernite sample in platinum crucible with $100 \mathrm{mg}$ of sodium or potassium carbonate in a muffle furnace at $1000^{\circ} \mathrm{C}$ for 5 minutes, followed by dissolution in $10 \mathrm{ml}$ of water and $1 \mathrm{ml}$ of sulphuric acid $1 \mathrm{M}$ or 1 $\mathrm{ml}$ of hydrochloric acid $1 \mathrm{M}$. The clear solution was then transferred and diluted with water in a $25 \mathrm{ml}$ volumetric flask containing $2.5 \mathrm{ml}$ of scandium solution (100 mg/l) as internal standard. A calibration protocol was adopted with a blank solution and a series of 5 solutions prepared with concentration ranging between $0.05 \mathrm{amd} 1.0 \mathrm{mg} / \mathrm{l}$ for each element (using CRM multi elemental standard mix for ICP). Results and instrumental parameters are given in Table 2.

\section{6) Determination of $\mathrm{C}, \mathrm{N}$, and $\mathrm{H}$}

200-300 $\mathrm{mg}$ of mineral sample were decomposed at $950^{\circ} \mathrm{C}$ in an elementary analyzer LECO Truspec CHN, in excess of oxygen for 90 seconds. The decomposition products were transferred to a second furnace (Afterburner) at $850^{\circ} \mathrm{C}$ for a further oxidation and particulate removal. After collection and homogenization of the gases in a container of 4.5 liters at $50^{\circ} \mathrm{C}$, Infrared absorption detectors were used to measure the $\mathrm{CO}_{2}$ and $\mathrm{H}_{2} \mathrm{O}$ concentration (as the $\mathrm{C}$ concentration was measured in the form of $\mathrm{CO}_{2}$ and the $\mathrm{H}$ one in the form of $\mathrm{H}_{2} \mathrm{O}$ ). A different portion of the decomposition products was instead transferred in a stream of helium through a copper catalyst in order to convert $\mathrm{NO}_{\mathrm{x}}$ to $\mathrm{N}_{2}$ and to remove oxygen, carbon dioxide and water. A thermal conductivity detector was used to determine the $\mathrm{N}_{2}$ content. EDTA, sodium tetra-borate deca-hydrate, boric acid, calcium carbonate, sodium nitrate and acid oxalic di-hydrate were employed as calibration standards. The measured fractions were: $\mathrm{C}<0.02 \mathrm{wt} \%$ (uncertainty not determined), $\mathrm{N}<0.02 \mathrm{wt} \%$ (uncertainty not determined), and $\mathrm{H}=3.0(2) \mathrm{wt} \%$.

A representative chemical composition of kernite from the Kramer deposit is given in Table 3, and its experimental chemical formula is virtually identical to the ideal one: $\mathrm{Na}_{2} \mathrm{~B}_{4} \mathrm{O}_{6}(\mathrm{OH})_{2} \cdot 3 \mathrm{H}_{2} \mathrm{O}$. 


\section{7) Single-crystal $X$-ray and neutron diffraction}

\section{1) X-ray and neutron data collections and treatments}

Single-crystal X-ray diffraction data were collected, at room temperature, with a Rigaku XtaLABSynergy-i diffractometer, equipped with a PhotonJet-i MoKa microfocus source and a HyPix-6000HE Hybrid Photon Counting (HPC) detector, at the Earth Science Dept. Univ. Milan. To maximize the reciprocal space coverage and the quality of the intensity data, a series of collection runs were optimised using the ad hoc routine of the CrysAlisPro ${ }^{\mathrm{TM}}$ suite (Rigaku - Oxford Diffraction 2019), with $\omega$ scan strategy, step size of $0.5^{\circ}$ and an exposure time per frame of $2 \mathrm{~s}$. A total number of 13010 reflections up to $2 \theta_{\max }$ of $60^{\circ}$ was collected (with $-9 \leq h \leq+8,-12 \leq k \leq+12$ and $-19 \leq l \leq$ $+20)$, out of which 2296 were unique $\left(R_{\text {int }}=0.0361\right.$, Laue class $\left.2 / m\right)$ and 1908 with $F_{0}>4 \sigma\left(F_{0}\right)$, giving a metrically monoclinic unit-cell with: $a=6.9983(3), b=9.1375(3), c=15.6389(7) \AA, \beta=$ $108.832(5)^{\circ}$ and $V=946.53(7) \AA^{3}$ (Table 4). Corrections for Lorentz-polarization effects and (semiempirical) X-ray absorption were applied using the ABSPACK routine, implemented in the CrysAlisPro $^{\mathrm{TM}}$ package (Rigaku - Oxford Diffraction 2019). The systematic extinctions were consistent with the space group $P 21 / c$. X-ray intensity data were then processed with the $E$ STATISTICS program, implemented in the WinGX package (Farrugia 1999): the statistics of distributions of the normalized structure factors showed that the structure is centrosymmetric at $\sim 93 \%$ likelihood (the Sheldrick's $\left|E^{2}-1\right|$ criterion is 0.969).

Single-crystal neutron diffraction data were collected at low temperature from a crystal of kernite (approx. $3 \times 2 \times 2 \mathrm{~mm}^{3}$ ) on the four-circle diffractometer D9 at the Institut Laue-Langevin (ILL), Grenoble (Gatta et al. 2019b). The crystal was glued on a vanadium pin and placed on a closecircuit displex device operated at 20.0(5) K (Archer and Lehmann 1986). The wavelength of 0.8347 $\AA$, obtained from a $\mathrm{Cu}(220)$ monochromator, and a small two-dimensional area detector were used. The measurement strategy consisted of a series of $\omega$-scans or $\omega-2 \theta$ scans for low and high-Q reflections, respectively. The Bragg reflections were collected varying the $\omega$-range as a function of the instrument resolution curve. A total number of 3434 reflections were collected (with $-10 \leq h \leq$ $+10,0 \leq k \leq+18$ and $-23 \leq l \leq+24)$, out of which 3161 were unique $(R$ int $=0.0488$, Laue class $2 / m)$ and 2656 with $F_{\mathrm{o}}>4 \sigma\left(F_{\mathrm{o}}\right)$, with $d_{\min }=0.59 \AA$ (Table 4). Intensity integration, background and Lorentz factor correction of the scans were done with the Racer program (written by Clive Wilkinson and Garry McIntyre, ILL integration program suite, https://forge.ill.fr/projects/sxtalsoft/repository/show/racer). The lattice was found to be metrically monoclinic (Table 4), and consistent with the X-ray experimental findings reported above. Absorption correction was applied, based on composition and shape of the crystal using the ILL 
program Datap (the current version of this program is available online on https://forge.ill.fr/). The reflection conditions were found to be consistent with the space group $P 21 / c$. The Wilson plot and the statistics of distributions of the normalized structure factors showed that the structure is centrosymmetric at $\sim 91 \%$ likelihood (the Sheldrick's $\left|E^{2}-1\right|$ criterion is 0.958 ).

Further details pertaining to the X-ray and neutron data collection strategies are listed in Table 4 (deposited).

\section{2) $X$-ray and neutron structure refinements}

Anisotropic crystal-structure refinements, based on the X-ray and neutron intensity data, collected at room and at low $T$, respectively, were conducted in the space group $P 2_{1} / C$ using the SHELXL-97 software (Sheldrick 1997, 2008), and starting from the structure model of Cooper et al. (1973), without any H atom. Neutral X-ray scattering factors of $\mathrm{Na}, \mathrm{B}, \mathrm{O}$ and $\mathrm{H}$ were taken from the International Tables for X-ray Crystallography (Vol. C) and used for the X-ray refinement, whereas neutron scattering lengths of $\mathrm{Na}, \mathrm{B}, \mathrm{O}$ and $\mathrm{H}$ were taken from Sears (1986). Secondary isotropic extinction effect was corrected according to the formalism of Larson (1967).

For both the refinements (i.e., X-ray at $293 \mathrm{~K}$ and neutron at $20 \mathrm{~K}$ ), convergence was rapidly achieved after the first cycles, with a series of residual peaks in the final difference-Fourier map of the electron or nuclear density (positive for the X-ray refinement, negative for the neutron refinement). The complex configuration of the $\mathrm{H}$ population was first modelled on the basis of the neutron data, and then implemented in the X-ray refinement. The negative residual peaks found in the difference-Fourier map of the nuclear density were assigned to the $\mathrm{H}$ sites in the next cycles (i.e, $\mathrm{H}$ has a negative neutron scattering length). Shape and magnitude of the minima in the differenceFourier maps showed no evidence of positional or dynamic disorder for six of the H sites (i.e., H1H6, Table 5). However, evidence of disorder was observed for the $\mathrm{H}$ population bonded to the (opposite) $\mathrm{O} 8$ and $\mathrm{O} 11$ sites, which are vertices of the $\mathrm{Na} 1$ and $\mathrm{Na} 2$ polyhedra, respectively (Fig. 2, Table 5). After a series of tests, the best figures of merit was obtained with three $\mathrm{H}$ sites bonded to $\mathrm{O} 8$ [i.e., H6, H72 and H82, with site occupancy factor s.o.f.(H6) = 1 and s.o.f.(H72)+s.o.f.(H82) = 1] and three bonded to $\mathrm{O} 11$ [i.e., H1, $\mathrm{H} 71$ and H81, with s.o.f. $(\mathrm{H} 1)=1$ and s.o.f. $(\mathrm{H} 71)+$ s.o.f.(H81) $=1$ ], with the following mutually exclusive configurations: (H6-O8-H82 + H1-O11-H71) and (H6-O8H72 + H1-O11-H81) (Fig. 2, Table 5). With such a structure model, convergence was achieved and the variance-covariance matrix showed no significant correlation among the refined variables; all the principal mean-square atomic displacement parameters were positive (including those for the $\mathrm{H}$ sites, Table 6) and the final $R_{1}(F)=0.0723$, for 2656obs./226par. (Table 4 - deposited). 
Implementing the structure model based on the neutron refinement, even convergence of the $\mathrm{X}$-ray refinement was rapidly achieved, with no significant correlation among the refined variables. The final $R_{1}(F)=0.0324$, for 1908obs./193par. (Table 4 - deposited).

Additional details pertaining to structure refinements are given in Table 4 (deposited). Atomic coordinates and displacement parameters are listed in Tables 5 (deposited) and 6 (deposited); selected interatomic distances and angles are given in Table 7.

In order to corroborate (or deny) the structure model based on the neutron least-square refinement, with its disordered $\mathrm{H}$-sites configuration, nuclear density distribution was also analysed by the maximum-entropy method (MEM), using the program DYSNOMIA (Momma et al. 2013) and the graphical representation of nuclear density maps by VESTA (Momma and Izumi 2011). The nuclear density maps were obtained from the single-crystal neutron data collected at $20 \mathrm{~K} .2435$ unique reflections with $I / \sigma(I)>3$ where used in the MEM calculation giving rise a final $R(F)$ and $w R(F)$ of 3.7 and $3.5 \%$, respectively. A grid of $256 \times 256 \times 256$ voxels were used to obtain a detailed density map. Fig. 3 shows a section of the nuclear density function corresponding to the $(0.1,0.5$, 0.6) plane. This plane was selected as $\mathrm{O} 8, \mathrm{O} 11$ and symmetry-related $\mathrm{H}_{2} \mathrm{O}$ molecules lay on it.

\section{Discussion and Implications}

Chemical and structural analysis of the kernite sample under investigation confirm the general formula previously reported in the literature: $\mathrm{Na}_{2} \mathrm{~B}_{4} \mathrm{O}_{6}(\mathrm{OH})_{2} \cdot 3 \mathrm{H}_{2} \mathrm{O}$. The only potential substituents of $\mathrm{Na}^{+}$here detected, distributed in the two independent $\mathrm{Na} 1$ and $\mathrm{Na} 2$ sites and giving distorted coordination polyhedra with $\mathrm{CN}=6$, are represented by $\mathrm{Mg}^{2+}$ and $\mathrm{K}^{+}$, but their sum is less than 0.01 a.p.f.u. (Table 3). Similarly, the only potential substituents of $\mathrm{B}^{3+}$ (in tetrahedral coordination) are $\mathrm{Si}^{4+}$ and $\mathrm{Al}^{3+}$, but for less than 0.01 a.p.f.u. (Tables 2 and 3). Even the $\mathrm{F}^{-}$fraction, as potential $\mathrm{OH}-$ group substituent, is not significant (i.e., <0.01 a.p.f.u., Tables 2 and 3). The concentration of other minor elements and of the REE is substantially irrelevant, as shown in Tables 1 and 2. Overall, kernite does not show any significant isomorphic substitution, and thus cannot act as geochemical trap of technologically-relevant elements (e.g., Li or REE). This finding can be compared with the results that we recently obtained on other borates: even in colemanite $\left(\mathrm{Ca}_{3}\left[\mathrm{~B}_{3} \mathrm{O}_{4}(\mathrm{OH})_{3}\right] \cdot \mathrm{H}_{2} \mathrm{O}\right.$, from the Bigadiç Mine, Balikesir Province, Marmara Region, Turkey; Lotti et al. 2018, 2019) and in kurnakovite $\left(\mathrm{Mg}\left[\mathrm{B}_{3} \mathrm{O}_{3}(\mathrm{OH})_{5}\right] \cdot 5 \mathrm{H}_{2} \mathrm{O}\right.$, from the Kramer Deposit, Mohave desert, Kern County, California; Gatta et al. 2019a) no significant isomorphic substituents were found, so that the experimental formulae were virtually identical to the ideal ones. In this light, the surprising chemical purity observed for kernite in this study, and previously in colemanite and kurnakovite (for which a similar chemical analytical 
protocol was used; Gatta et al. 2019a; Lotti et al. 2018, 2019), appears not to be a peculiarity of the single species or of a given deposit, but it is rather a common feature of the hydrous borates which share the same geological environment: lacustrine deposits with hydrothermal activity. The reasons for such a high purity are still obscure: whereas it is more difficult to find a substituent of B (in CN 3 or 4), which generates a low chemical strain into the structure, $\mathrm{Na}$ could be efficiently replaced by alkaline or even earth-alkaline cations, if we consider the bonding configuration of the (distorted) Napolyhedra in the kernite structure (Table 7). The same considerations, though referred to different cations, were previously done on colemanite and kurnakovite by Gatta et al. (2019a). However, the chemical composition of a given hydrothermal mineral it is not only dictated by its crystal structure, but even by the composition of the solution. In this light, a possible explanation is that crystal nucleation and growth could promote purification by iterated dissolution and recrystallization.

The structure model of kernite obtained in this study, based on X-ray and neutron diffraction data, is (partially) consistent with that previously reported by Cooper et al. (1973). The structure is built by two crystallographically independent triangular $\mathrm{BO}_{2} \mathrm{OH}$ groups (with the $\mathrm{B}$-ions in $s p^{2}$ electronic configuration) and two tetrahedral $\mathrm{BO}_{4}$ groups (with the $\mathrm{B}$-ions in $s p^{3}$ electronic configuration), which share corner-bridging $\mathrm{O}$ atoms to form 3-fold rings (3B: $\Delta+2 \mathrm{~T}$ units), giving chains running along [010] and held together by hydrogen bonding (Fig. 1). Two independent Na sites are sixfold-coordinated by $\mathrm{O}$ atoms, $\mathrm{OH}$-groups and $\mathrm{H}_{2} \mathrm{O}$ molecules, though the bonding configuration of the strongly distorted $\mathrm{Na} 2$-polyhedron would suggest a $\mathrm{CN}=5+1$, as five $\mathrm{Na} 2-\mathrm{O}$ distances are shorter than $2.5 \AA$ and one is about $3.1 \AA$ (Table 7, room- $T$ X-ray refinement).

The X-ray (data collected at $293 \mathrm{~K}$ ) and neutron (data collected at $20 \mathrm{~K}$ ) structure refinements consistently show that:

1) The triangular $\left[\mathrm{BO}_{2}(\mathrm{OH})\right]$-groups have an almost ideal configuration, with $\Delta(\mathrm{B} 1-\mathrm{O})_{\max } \sim$ $\Delta(\mathrm{B} 4-\mathrm{O})_{\max } \sim 0.02-0.03 \AA$ (i.e., the difference between the longest and the shortest bond distances), average O-B-O angles of $120^{\circ}$ (ranging between $118.5^{\circ}-122.8^{\circ}$ for $\mathrm{B} 1-$ and $115.3^{\circ}-124.4^{\circ}$ for B4-triangular groups), and aplanarity $<1^{\circ}$ (here defined as the average angle described by the plane on which the 3-oxygen sites lie and each of the three independent $\mathrm{B}-\mathrm{O}_{n}$ vectors); the tetrahedral $\left[\mathrm{BO}_{4}\right]$-groups are only slightly distorted, with $\Delta(\mathrm{B} 2-\mathrm{O})_{\max } \sim \Delta(\mathrm{B} 3-\mathrm{O})_{\max } \sim 0.06 \AA$; the $\mathrm{Na1O}_{4}(\mathrm{OH})\left(\mathrm{OH}_{2}\right)$ polyhedron has $\Delta(\mathrm{Na1}-\mathrm{O})_{\max } \sim$ $0.22 \AA$ and is less distorted than the $\mathrm{Na}_{2} \mathrm{O}_{2}(\mathrm{OH})\left(\mathrm{OH}_{2}\right)_{3}$ one with $\Delta(\mathrm{Na} 2-\mathrm{O})_{\max } \sim 0.7 \AA$. The B-O and Na-O distances are slightly different as a function of bonding configuration of the oxygen sites (i.e., oxygen of a $\mathrm{OH}$ - or $\mathrm{OH}_{2}$-group or as a bridging site between polyhedra). 
2) Three crystallographically independent $\mathrm{H}_{2} \mathrm{O}$ molecules occur in the structure of kernite (i.e., H3-O10-H5, H6-O8-H72 or H6-O8-H82, H1-O11-H71 or H1-O11-H81, Table 7). Among those, two are affected by positional disorder of the $\mathrm{H}$ sites, so that two mutually exclusive configurations occur, here modelled as: (H6-O8-H82 + H1-O11-H71) or (H6-O8-H72 + H1-O11-H81) (Figs. 2 and 4). The results obtained by the structure refinements are consistent with a model based on a static disorder of the $\mathrm{H}$ sites, rather than a dynamic one. The nuclear density distribution around pairs of the oxygen atoms $\mathrm{O} 8$ and $\mathrm{O} 11$ obtained by MEM confirm a double well potential, which gives rise to a splitting of the H sites (Fig. 3). The nuclear density maps indicate that the $\mathrm{H} 71 / \mathrm{H} 72$ and $\mathrm{H} 81 / \mathrm{H} 82$, and those related by symmetry, could be modelled using a statically disordered configuration with hydrogen atoms filling two well defined sites. The unbalanced nuclear density between each hydrogen position suggests a non-equivalent occupancy of each site, in agreement with the refined structural model (Table 5). However, other scenarios could also explain the observed $\mathrm{H}$ network. Two different hydrogen networks are derived from the current model, one configuration if $\mathrm{H} 71$ and $\mathrm{H} 82$ are present and a second for the case of $\mathrm{H} 72$ and H81. The H71 and H72 sites could be seen as a splitting of the hydrogen atom located between two opposite oxygen sites (in this case: O8 and O11). A similar scenario was reported for ice phases, where the jump between both configurations was ascribed to "proton tunnelling" (Bove et al. 2009, Yen and Gao 2015). The tunnelling occurs at low temperature when a proton has the same probability to be located on each minimum of a double well potential. Therefore, this effect involves, in most of the cases, symmetric potentials. In our case, the nuclear density maps obtained from the MEM clearly show that both sites have not the same density, and therefore a different energy barrier occurs in each well of potential. Although a proton tunnelling could not completely discarded, based on the current results this scenario is unlikely.

It is worth noting that a similar kind of disorder of the $\mathrm{H}_{2} \mathrm{O}$ hydrogen atoms also occurs in colemanite (Lotti et al. 2018), leading to two possible (and mutually exclusive) H-bonding configurations.

3) Geometrically, the three crystallographically independent $\mathrm{H}_{2} \mathrm{O}$ molecules show: a) H-O-H angles ranging between $102^{\circ}$ and $108^{\circ}$ (neutron data), consistent with the observed $\mathrm{H}-\mathrm{O}-\mathrm{H}$ angles in solid-state materials (e.g., Steiner 1998, and references therein; Gatta et al. 2008, 2012, 2019a; Lotti et al. 2018); b) O-H distances (corrected for "riding motion effect" following Busing and Levy 1964) ranging between 0.98 and $1.05 \AA$ (neutron data); c) O- 
H...O angles $\geq 162^{\circ}$ (Table 7), approaching a configuration energetically favourable (i.e.,

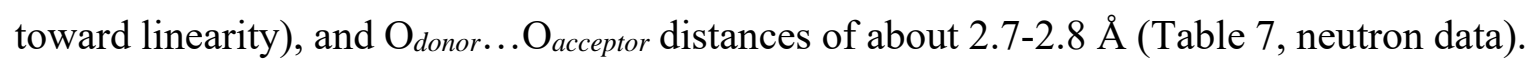
The two independent hydroxyl groups (i.e., O6-H2 and O7-H4, Table 7) show O-H distances (corrected for "riding motion effect") ranging between 0.98-0.99 $\AA$, $\mathrm{O}_{\text {donor... }} \mathrm{O}_{\text {acceptor }}$ distances between 2.8-3.3 $\AA$, and O-H...O $>172^{\circ}$ (Table 7, neutron data).

4) If we exclude $\mathrm{O} 4$ and $\mathrm{O} 9$, all the other oxygen sites in the structure of kernite are involved in H-bonding, as donors or as acceptors (Fig. 4, Table 7).

5) The X-ray and neutron refinements, based on the intensity data collected at 293 and $20 \mathrm{~K}$ respectively, show that this borate does not experience any $T$-induced phase transition, within the $T$-range investigated. The two structure models are virtually identical. As expected, there is a drastic reduction of the magnitude of the atomic displacement ellipsoids at low $T$, as shown by the $U_{\text {eq }}$ values (calculated as one third of the trace of the orthogonalised $U_{i j}$ tensor, Tables 5 and 6 - deposited). Some of the atomic displacement ellipsoids are significantly anisotropic at $20 \mathrm{~K}$ (Table 6 - deposited, Figs. 1, 2 and 4), though still realistic. We are inclined to believe that this is the twofold effect generated by: a) a not efficient correction for the extinction effect with the isotropic model of Larson (1967) and b) the static disorder of the $\mathrm{H}$-sites belonging the $\mathrm{H}_{2} \mathrm{O}$ molecules of the Na1- and $\mathrm{Na} 2-$ polyhedra, which affect all the sites of the Na-coordination shells.

The structure model obtained in this study is consistent with the FT-IR and Raman spectra of kernite reported and interpreted by Jun et al. (1995), Kloprogge and Frost (1999) and Silva et al. (2018). The experimental findings of this study confirm that also in kernite, as for other hydrous borates (Gatta et al. 2019a), the H-bonding network is complex, pervasive and play a primary role into the crystalline edifice. This could also explain the almost insignificant $\mathrm{F}^{-}$(or even $\mathrm{Cl}^{-}$) vs. $\mathrm{OH}^{-}$substitution (Table 3). The first implication on potential utilizations of kernite is that any environmental variable able to affect the H-bonding network (i.e., under chemical, thermal or compressional stress conditions) can generate a structure instability. This can be deduced, for example, by the thermal behaviour of kernite reported by Sennova et al. (2005; without structure refinement) or by the static compressional behaviour reported by Silva et al. (2018; without structure refinement), along with the reported solubility in water (Mineral Data Publishing, http://rruff.info/doclib/hom/kernite.pdf). However, the mechanisms, at the atomic scale, that govern the thermal and compressional behaviour of kernite are still obscure, and will be the aim of our future experiments, based on in situ X-ray diffraction investigations. 
The solubility of kernite in water (or in other polar solvents) could be considered a positive feature for a mineral commodity of $\mathrm{B}$, which contains up to $15 \mathrm{wt} \%$ of elemental $\mathrm{B}\left(\mathrm{B}_{2} \mathrm{O}_{3} \sim 50 \mathrm{wt} \%\right)$. However, the potential utilization of kernite as B-rich aggregate in Portland cement concretes (used as radiationshielding materials for the elevated ability of ${ }^{10} \mathrm{~B}$ to absorb thermal neutrons) is hindered by its high $\mathrm{Na}$ content ( $16 \mathrm{wt} \%$ of elemental $\mathrm{Na} ; \mathrm{Na}_{2} \mathrm{O} 21.3 \mathrm{wt} \%$ ), which could promote deleterious reactions for the durability of cements (e.g., the so-called "alkali-silica reactions" - ASR). The national standards are not identical in the different countries but, in general, the alkali content in ordinary

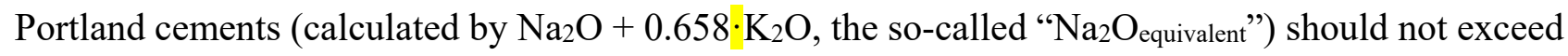
$0.60 \mathrm{wt} \%$, in order to avoid or minimize the risk of ASR. However, it is still obscure the role of $\mathrm{Na}$ and B in Sorel cements (i.e., magnesium oxychloride cements), leaving room for experiments in this direction. Sorel cements are not used as reinforced concretes, as basically incompatible with steel reinforcement because the presence of chloride, but are commonly used to make floor tiles and panels for fire protection. Could B-additivated Sorel cements be efficiently used for the production of radiation-shielding tiles or panels?

\section{Acknowledgements}

The authors thank the Institut Laue-Langevin (Grenoble, France) for the allocation of the beamtime, further information could be consulted under the identifier DOI:10.5291/ILL-DATA.DIR-179. GDG and PL acknowledge the support of the Italian Ministry of Education (MIUR) through the projects 'Dipartimenti di Eccellenza 2018-2022' and 'PRIN2017 - Mineral reactivity, a key to understand largescale processes'. PL acknowledge the support of the University of Milan through the project 'PSR2018 - Georisorse e Geomateriali'. The Associate Editor and an anonymous reviewer are thanked for their suggestions aimed to improve the quality of the manuscript. 


\section{References}

Amoros, J.L.P. (1945) La estructura de la kernita. Euclides, 57-58, 599-608.

Archer, J. and Lehmann, M.S. (1986) A simple adjustable mount for a two-stage cryorefrigerator on an Eulerian cradle. Journal of Applied Crystallography, 19, 456-459.

Bove, L.E., Klotz, S., Paciaroni, A., and Sacchetti, F. (2009) Anomalous Proton Dynamics in Ice at Low Temperatures. Physical Review Letter, 103, 165901-4.

Busing, W.R. and Levy, H.A. (1964) The effect of thermal motion on the estimation of bond lengths from diffraction measurements. Acta Crystallographica, 17, 142-146.

Carter, R.S., Palevsky, H., Myers, V.W., and Hughes, D.J. (1953) Thermal neutron absorption cross sections of boron and gold. Physical Review, 96, 716-721.

Christ, C.L. and Garrels, R.M. (1959) Relations among sodium borate hydrates at the Kramer deposit, Born, California. American Journal of Science, 257, 516-528.

Cialdi, G., Corazza, E., and Sabelli, C. (1967) La struttura cristallina della kernite, $\mathrm{Na}_{2} \mathrm{~B}_{4} \mathrm{O}_{6}(\mathrm{OH})_{2} \cdot 3 \mathrm{H}_{2} \mathrm{O}$. Rendiconti dell'Accademia Nazionale dei Lincei, Ser. VIII, 42, 236-251.

Cipriani, C. (1958) Ricerche sulla disidratazione di alcuni borati naturali. Atti della Società Toscana di Scienze Naturali, 65A, 284-322.

Cooper, W.F., Larsen, F.K., and Coppens, P. (1973) Electron population analysis of accurate diffraction data. V. Structure and one-center charge refinement of the light-atom mineral kernite, $\mathrm{Na}_{2} \mathrm{~B}_{4} \mathrm{O}_{6}(\mathrm{OH})_{2} \cdot 3 \mathrm{H}_{2} \mathrm{O}$. American Mineralogist, 58, 21-31.

European Commission (2017) Critical Raw Materials for the EU. Document 52017DC0490, https://ec.europa.eu/growth/sectors/raw-materials/specific-interest/critical_en.

Farrugia, L.J. (1999) WinGX suite for small-molecule single-crystal crystallography. Journal of Applied Crystallography, 32, 837-838.

Gatta, G.D., Rotiroti, N., McIntyre, G.J., Guastoni, A., and Nestola, F. (2008) New insights into the crystal chemistry of epididymite and eudidymite from Malosa, Malawi: a single-crystal neutron diffraction study. American Mineralogist, 93, 1158-1165.

Gatta, G.D., McIntyre, G.J., Swanson, G.J., and Jacobsen, S.D. (2012) Minerals in cement chemistry: a single-crystal neutron diffraction and Raman spectroscopic study of thaumasite, $\mathrm{Ca}_{3} \mathrm{Si}(\mathrm{OH})_{6}\left(\mathrm{CO}_{3}\right)\left(\mathrm{SO}_{4}\right) \cdot 12 \mathrm{H}_{2} \mathrm{O}$. American Mineralogist, 197, 1060-1069.

Gatta G.D., Guastoni A., Lotti P., Guastella G., Fabelo O., Fernandez-Diaz. M.T. (2019) A multi-methodological study of kurnakovite: A potential B-rich aggregate. American Mineralogist, 104, 1315-1322. 
Gatta, G.D., Fabelo-Rosa O.R., and Fernandez-Diaz M.T. (2019b) Crystal chemistry of kernite mineral $\left[\mathrm{Na}_{2} \mathrm{~B}_{4} \mathrm{O}_{6}(\mathrm{OH})_{2} \cdot 3 \mathrm{H}_{2} \mathrm{O}\right]$ : a sustainable approach for boron-based cements. Experimental Report, Institut Laue-Langevin (ILL), doi:10.5291/ILL-DATA.DIR-179.

Giese, R. F. Jn. (1966) Crystal structure of kernite, $\mathrm{Na}_{2} \mathrm{~B}_{4} \mathrm{O}_{6}(\mathrm{OH})_{2} \cdot 3 \mathrm{H}_{2} \mathrm{O}$. Science, 154, $1453-$ 1454.

Grice, J.D., Burns, P.C., and Hawthorne, F.C. (1999) Borate minerals. II. A hierarchy of structures based upon the borate fundamental building block. Canadian Mineralogist, 37, 731-762.

Heller, G. (1986) A survey of structural types of borates and polyborates. Topics in Current Chemistry, 131, 39-98.

Hurlbut, C. S. Jr., Aristarain, L.F., and Erd, R.C. (1973) Kernite from Tincalayu, Salta, Argentina. American Mineralogist, 58, 308-313.

Jun, L., Shuping, X., and Shiyang, G. (1995) FT-IR and Raman spectroscopic study of hydrated borates. Spectrochimica Acta Part A: Molecular and Biomolecular Spectroscopy, 51, 519-532.

Kloprogge, J.T. and Frost, R.L. (1999) Raman microscopic study of some borate minerals: Ulexite, kernite, and inderite. Applied spectroscopy, 53, 356-364.

Larson, A.C. (1967) Inclusion of secondary extinction in least-squares calculations. Acta Crystallographica, 23, 664-665.

Lotti, P., Gatta, G.D., Comboni, D., Guastella, G., Merlini, M., Guastoni, A., and Liermann, H.P. (2017) High-pressure behavior and $P$-induced phase transition of $\mathrm{CaB}_{3} \mathrm{O}_{4}(\mathrm{OH})_{3} \cdot \mathrm{H}_{2} \mathrm{O}$ (colemanite). Journal of American Ceramic Society, 100, 2209-2220.

Lotti, P., Gatta, G.D., Demitri, N., Guastella, G., Rizzato, S., Ortenzi, M.A., Magrini, F., Comboni, D., Guastoni, A., and Fernandez-Diaz, M.T. (2018) Crystal-chemistry and temperature behavior of the natural hydrous borate colemanite, a mineral commodity of boron. Physics and Chemistry of Minerals, 45, 405-422.

Lotti, P., Comboni, D., Gigli, L., Carlucci, L., Mossini, E., Macerata, E., Mariani, M., and Gatta, G.D. (2019) Thermal stability and high-temperature behavior of the natural borate colemanite: An aggregate in radiation-shielding concretes. Construction and Building Materials, 203, 679-686.

Momma, K., and Izumi, F. (2011) Vesta 3 for three-dimensional visualization of crystal, volumetric and morphology data. Journal of Applied Crystallography, 44, 1272-1276.

Momma, K., Ikeda, T., Belik, A.A., and Izumi, F. (2013) Dysnomia, a computer program for maximum-entropy method (MEM) analysis and its performance in the MEM-based pattern fitting. Powder Diffraction, 28, 184-193. 
Morgan, V. and Erd, R.C. (1969) Minerals of the Kramer borate district, California. California

Division of Mines and Geology Mineral Information Service, 22, pp. 143-153 and 165-172.

Noble, L.F. (1926) Borate deposits in the Kramer district, Kern County, California. U.S. Geological Survey Bulletin, 785, 45-61.

Obert, L. and Long, A.E. (1962) Underground borate mining, Kern County, California. U.S. Bureau of Mines Report of Investigation, 6110, 1-12.

Palmer M.R. and Swihart, G.H. (1996) Boron Isotope Geochemistry: An Overview. In L.M. Anovitz, E.S. Grew (Eds.), Boron: Mineralogy, Petrology, and Geochemistry, Review in Mineralogy 33, Mineralogical Society of America, Chantilly, pp. 709-744.

Puffer, J.H. (1975) The Kramer borate mineral assemblage. Mineralogical Record, 6, 84-91.

Rauch, H., and Waschkowski, W. (2002) Neutron Scattering Lengths. In A.J. Dianoux, G. Lander (Eds.), Neutron Data Booklet, first ed., Institut Laue Langevin, Grenoble, pp. 1-18.

Schaller, W. T. (1927) Kernite, a new sodium borate. American Mineralogist, 12, 24-25.

Schaller, W. T. (1930) Borate minerals from the Kramer district, Mohave Desert, California. U.S. Geological Survey Professional Paper, 158, 137-170.

Sears, V.F. (1986) Neutron Scattering Lengths and Cross-Sections. In K. Sköld and D.L. Price, Eds., Neutron Scattering, Methods of Experimental Physics, Vol. 23A, Academic Press, New York, pp. 521-550.

Sennova, N.A., Bubnova, R.S., Filatov, S.K., Paufler, P., Meyer, D.C., Levin, A.A., and Polyakova, I.G. (2005) Room, low, and high temperature dehydration and phase transition of kernite in vacuum and in air. Crystal Research and Technology, 40, 563-572.

Sheldrick, G.M. (1997) SHELXL-97. Programs for crystal structure determination and refinement. University of Göttingen, Germany.

Sheldrick, G.M. (2008) A short history of SHELX. Acta Crystallographica, A64, 112-122.

Siefke, J.W. (1991) The Boron open Pit Mine at the Kramer Borate Deposit. The Diversity of Mineral and Energy Resources of Southern California. In M.A. McKibben, Ed., Society of Economic Geologist Guidebook Series, 12, 4-15.

Silva, M., O'Bannon, E.F., and Williams, Q. (2018) A vibrational spectroscopic study of kernite to $25 \mathrm{GPa}$ : Implications for the high-pressure stability of borate polyhedra. American Mineralogist, 103, 1306-1318.

Steiner, T. (1998) Opening and narrowing of the water H-O-H angle by hydrogen-bonding effects: Re-inspection of neutron diffraction data. Acta Crystallographica, B54, 464-470. 
U.S.G.S. (2018) Mineral commodity summaries 2018. U.S. Geological Survey, 200 p., Reston, 592 Virginia, U.S.A. U.S.G.S. (2019) Mineral commodity summaries 2019. U.S. Geological Survey, 200 p., Reston, 594 Virginia, U.S.A. Yen, F. and Gao, T. (2015) Dielectric Anomaly in Ice near 20 K: Evidence of Macroscopic Quantum Phenomena. Journal of Physical Chemistry Letter, 6, 2822-2825.

597

598

599

600

601

602

603 
604

605

606

607

608

609

610

611

612

613

614

615

616

617

618

619

620

621

622

623

624

625

626

Table 1. REE concentration by ICP-AES (see text for details).

\begin{tabular}{c|cccc}
\hline & \%m/m & ICP-AES $(\mathrm{nm})$ & LOD & LOQ \\
\hline $\mathrm{Ce}_{2} \mathrm{O}_{3}$ & $<$ LOD & 413.764 & 0.003 & 0.01 \\
$\mathrm{Dy}_{2} \mathrm{O}_{3}$ & $<$ LOD & 353.170 & 0.0001 & 0.0003 \\
$\mathrm{Er}_{2} \mathrm{O}_{3}$ & $<$ LOD & 369.265 & 0.002 & 0.007 \\
$\mathrm{Eu}_{2} \mathrm{O}_{3}$ & $<$ LOD & 381.967 & 0.0001 & 0.0003 \\
$\mathrm{Gd}_{2} \mathrm{O}_{3}$ & $<$ LOD & 342.247 & 0.0003 & 0.001 \\
$\mathrm{Ho}_{2} \mathrm{O}_{3}$ & $<$ LOD & 345.600 & 0.0001 & 0.0003 \\
$\mathrm{La}_{2} \mathrm{O}_{3}$ & $<$ LOD & 398.852 & 0.0001 & 0.0003 \\
$\mathrm{Lu}_{2} \mathrm{O}_{3}$ & $<$ LOD & 261.542 & 0.0002 & 0.0006 \\
$\mathrm{Nd}_{2} \mathrm{O}_{3}$ & $<$ LOD & 406.109 & 0.0002 & 0.0006 \\
$\mathrm{Pr}_{2} \mathrm{O}_{3}$ & $<$ LOD & 390.844 & 0.0002 & 0.0006 \\
$\mathrm{Sm}_{2} \mathrm{O}_{3}$ & $<$ LOD & 359.260 & 0.0005 & 0.002 \\
$\mathrm{Sc}_{2} \mathrm{O}_{3}$ & $<$ LOD & 361.383 & 0.0005 & 0.002 \\
$\mathrm{~Tb}_{2} \mathrm{O}_{3}$ & $<$ LOD & 350.917 & 0.0005 & 0.002 \\
$\mathrm{Tm}_{2} \mathrm{O}_{3}$ & $<$ LOD & 313.126 & 0.004 & 0.015 \\
$\mathrm{Yb}_{2} \mathrm{O}_{3}$ & $<$ LOD & 328.937 & 0.0001 & 0.0003 \\
$\mathrm{Y}_{2} \mathrm{O}_{3}$ & $<$ LOD & 371.029 & 0.0001 & 0.0003 \\
$\mathrm{ThO}_{2}$ & $<$ LOD & 283.730 & 0.001 & 0.004 \\
$\mathrm{UO}_{2}$ & $<$ LOD & 385.958 & 0.01 & 0.04 \\
\hline Note: $\mathrm{LOD}:$ Limit of detection $(3 \sigma) ;$ LOQ: Limit of quantification $(10 \sigma)$ \\
\hline \multicolumn{5}{c}{}
\end{tabular}

Table 2. Concentration of other minor elements by ICP-AES (see text for details).

\begin{tabular}{lrc|lrc}
\hline & $\% \mathrm{~m} / \mathrm{m}$ & ICP-AES $(\mathrm{nm})$ & & $\% \mathrm{~m} / \mathrm{m}$ & ICP-AES $(\mathrm{nm})$ \\
\hline $\mathrm{Li}_{2} \mathrm{O}$ & $<0.01$ & 670.784 & $\mathrm{NiO}$ & $<0.01$ & 231.604 \\
$\mathrm{MgO}$ & 0.01 & 285.213 & $\mathrm{CuO}$ & $<0.01$ & 327.393 \\
$\mathrm{~K}_{2} \mathrm{O}$ & 0.02 & 766.490 & $\mathrm{Ag}_{2} \mathrm{O}$ & $<0.01$ & 328.068 \\
$\mathrm{Rb} 2 \mathrm{O}$ & $<0.02$ & 780.023 & $\mathrm{ZnO}$ & $<0.01$ & 206.200 \\
$\mathrm{Cs} 2 \mathrm{O}$ & $<0.02$ & 455.531 & $\mathrm{CdO}$ & $<0.01$ & 228.802 \\
$\mathrm{BeO}$ & $<0.01$ & 313.107 & $\mathrm{Al}_{2} \mathrm{O}_{3}$ & 0.01 & 396.153 \\
$\mathrm{CaO}$ & $<0.01$ & 317.933 & $\mathrm{Tl}_{2} \mathrm{O}$ & $<0.02$ & 190.801 \\
$\mathrm{BaO}$ & $<0.02$ & 233.527 & $\mathrm{PbO}^{2}$ & $<0.05$ & 220.353 \\
$\mathrm{TiO}_{2}$ & $<0.01$ & 334.940 & $\mathrm{P}_{2} \mathrm{O}_{5}$ & $<0.02$ & 213.617 \\
$\mathrm{ZrO}_{2}$ & $<0.01$ & 343.823 & $\mathrm{As}_{2} \mathrm{O}_{3}$ & $<0.02$ & 193.696 \\
$\mathrm{~V}_{2} \mathrm{O}_{5}$ & $<0.02$ & 292.464 & $\mathrm{Sb}_{2} \mathrm{O}_{3}$ & $<0.02$ & 206.836 \\
$\mathrm{Cr}_{2} \mathrm{O}_{3}$ & $<0.01$ & 267.716 & $\mathrm{Bi}_{2} \mathrm{O}_{3}$ & $<0.02$ & 223.061 \\
$\mathrm{MoO}_{3}$ & $<0.02$ & 202.031 & $\mathrm{SiO}_{2}$ & 0.01 & 251.611 \\
$\mathrm{MnO}$ & $<0.01$ & 257.610 & $\mathrm{SrO}_{2}$ & $<0.01$ & 407.771 \\
$\mathrm{Fe}_{2} \mathrm{O}_{3}$ & $<0.01$ & 238.204 & $\mathrm{~B}_{2} \mathrm{O}_{3}$ & $*$ & 249.677 \\
$\mathrm{CoO} \mathrm{O}$ & $<0.01$ & 228.616 & $\mathrm{Na}_{2} \mathrm{O}$ & $*$ & 589.592 \\
\hline$*$
\end{tabular}

* data were not reproducible and therefore discarded 
627

628

629

630

631

632

633

634

635

636

637

638

639

640

641

642

643

644

645

646

647

648

649

650

651

652

653

654

655

656

657

658

659

660

661

662

663

664

665

666

667

668

669

670

671

672

673

674

675

676

677

678

Table 3. Representative chemical composition of kernite from Kramer Deposit (Kern County, California), and empirical formula recalculated on the basis of eleven anions.

\begin{tabular}{|c|c|c|}
\hline Oxides & $W t \%$ & e.s.d. \\
\hline $\mathrm{B}_{2} \mathrm{O}_{3}$ & $\begin{array}{l}50.90 \\
\end{array}$ & \pm 0.20 \\
\hline $\mathrm{Na}_{2} \mathrm{O}$ & 22.55 & \pm 0.20 \\
\hline $\mathrm{SiO}_{2}$ & 0.01 & \pm n.d \\
\hline $\mathrm{Al}_{2} \mathrm{O}_{3}$ & 0.01 & \pm n.d \\
\hline $\mathrm{MgO}$ & 0.01 & \pm n.d \\
\hline $\mathrm{K}_{2} \mathrm{O}$ & 0.02 & $\pm \mathrm{n} . \mathrm{d}$ \\
\hline $\mathrm{F}^{-}$ & 0.01 & \pm n.d \\
\hline $\mathrm{H}_{2} \mathrm{O}$ & 26.40 & \pm 0.20 \\
\hline TOTAL & 99.91 & \\
\hline Elements & a.p.f.u. & \\
\hline $\mathrm{B}^{3+}$ & 3.99 & \\
\hline $\mathrm{Na}^{+}$ & 1.99 & \\
\hline $\mathrm{Si}^{4+}$ & $<0.01$ & \\
\hline $\mathrm{Al}^{3+}$ & $<0.01$ & \\
\hline $\mathrm{Mg}^{2+}$ & $<0.01$ & \\
\hline $\mathrm{K}^{+}$ & $<0.01$ & \\
\hline $\mathrm{F}^{-}$ & $<0.01$ & \\
\hline $\mathrm{H}^{+}$ & 8.02 & \\
\hline \multicolumn{3}{|c|}{$\begin{array}{l}\text { Empirical formula: } \\
\mathrm{Na}_{1.99} \mathrm{~B}_{3.99} \mathrm{O}_{6}(\mathrm{OH})_{2} \cdot 3.01 \mathrm{H}_{2} \mathrm{O} \\
\text { Ideal formula: } \\
\mathrm{Na}_{2} \mathrm{~B}_{4} \mathrm{O}_{6}(\mathrm{OH})_{2} \cdot 3 \mathrm{H}_{2} \mathrm{O}\end{array}$} \\
\hline
\end{tabular}


679

680

Table 4 (deposited). Details of neutron and X-ray data collections and refinements of kernite.

681

682

683

684

685

686

687

688

689

690

691

692

693

694

695

696

697

698

699

700

701

702

703

\begin{tabular}{l}
\hline$T(\mathrm{~K})$ \\
Crystal shape \\
Crystal volume (mm) \\
Crystal colour \\
Unit-cell parameters
\end{tabular}

Chemical formula Space Group

Z

Radiation type, $\lambda(\AA)$

Diffractometer

Data-collection method

$d_{\min .}(\AA)$

Measured reflections

Unique reflections

Unique reflections with $F_{o}>4 \sigma\left(F_{o}\right)$

Refined parameters

Extinction coeff.

$R_{\text {Int }}$

$R_{\sigma}$

$R_{1}(F)$ with $F_{o}>4 \sigma\left(F_{o}\right)$

$R_{1}(F)$ for all reflections

$w R_{2}\left(F^{2}\right)$

GooF

Residuals $\left(\mathrm{fm} / \AA^{3}, e^{-} / \AA^{3}\right)$

\section{0}

Prism

$3 \times 2 \times 2$

White

$a=6.996(1) \AA$

$b=9.128(3) \AA$

$c=15.608(3) \AA$

$\beta=109.06(3)^{\circ}$

$V=942.0(4) \AA^{3}$

$\mathrm{Na}_{2} \mathrm{~B}_{4} \mathrm{O}_{6}(\mathrm{OH})_{2} \cdot 3 \mathrm{H}_{2} \mathrm{O}$

$P 2_{1} / C$

4

Neutron CW, 0.8347

D9 four-circle - ILL

$\omega$-scans, $\omega-2 \theta$ scans

0.59

$-10 \leq h \leq+10$

$0 \leq k \leq+18$

$-23 \leq l \leq+24$

3434

3161

2656

226

$0.014(2)$

0.0488

0.0557

0.0723

0.0884

0.1491

1.636

$-1.9 /+2.5$
293

Prism

$0.22 \times 0.12 \times 0.11$

White

$a=6.9983(3) \AA$

$b=9.1375(3) \AA$

$c=15.6389(7) \AA$

$\beta=108.832(5)^{\circ}$

$V=946.53(7) \AA^{3}$

$\mathrm{Na}_{2} \mathrm{~B}_{4} \mathrm{O}_{6}(\mathrm{OH})_{2} \cdot 3 \mathrm{H}_{2} \mathrm{O}$

$P 2{ }_{1} / C$

4

$\mathrm{X}$-ray, $\mathrm{MoK \alpha}$

Rigaku XtaLABSynergy-i $\omega$-scans

0.71

$-9 \leq h \leq+8$

$-12 \leq k \leq+12$

$-19 \leq l \leq+20$

13010

2296

1908

193

$0.001(1)$

0.0361

0.0259

0.0324

0.0412

0.0655

1.519

$-0.3 /+0.5$

Note: Statistical parameters according to the Shelxl-97 definition (Sheldrick 1997, 2008). 
Table 5 (deposited). Refined fractional atomic coordinates and equivalent/isotropic displacement factors $\left(\AA^{2}\right)$ of kernite, based on the X-ray structure refinement at $293 \mathrm{~K}$ and neutron refinement at $20 \mathrm{~K} . U_{e q}$ is defined as one third of the trace of the orthogonalised $U_{i j}$ tensor.

\begin{tabular}{|c|c|c|c|c|c|c|c|c|c|c|}
\hline & & & $X$-ray & $293 K$ & & & & Neutron & $20 K$ & \\
\hline Site & s.o.f. & $x / a$ & $y / b$ & $z / c$ & $U_{\text {eq }}$ & s.o.f. & $x / a$ & $y / b$ & $z / C$ & $U_{\text {eq }} / U_{\text {iso }}$ \\
\hline Na1 & 1 & $0.31944(12)$ & $0.46480(8)$ & $0.31093(6)$ & $0.0245(2)$ & 1 & $0.3190(4)$ & $0.4638(2)$ & $0.3102(2)$ & $0.0067(7)$ \\
\hline $\mathrm{Na} 2$ & 1 & $0.18563(14)$ & $0.36644(9)$ & $0.07250(6)$ & $0.0353(2)$ & 1 & $0.1869(4)$ & $0.3681(2)$ & $0.0703(2)$ & $0.0073(8)$ \\
\hline $\mathrm{O} 1$ & 1 & $0.4874(2)$ & $0.52527(13)$ & $0.10281(8)$ & $0.0182(3)$ & 1 & $0.4865(2)$ & $0.52517(13)$ & $0.10184(13)$ & $0.0050(4)$ \\
\hline $\mathrm{O} 2$ & 1 & $0.55971(19)$ & $0.59894(13)$ & $0.25905(8)$ & $0.0157(3)$ & 1 & $0.5610(2)$ & $0.59800(12)$ & $0.25950(12)$ & $0.0038(4)$ \\
\hline $\mathrm{O} 3$ & 1 & $0.23252(19)$ & $0.70586(14)$ & $0.23145(9)$ & $0.0192(3)$ & 1 & $0.2321(2)$ & $0.70429(13)$ & $0.23132(13)$ & $0.0046(4)$ \\
\hline O4 & 1 & $0.46514(18)$ & $0.35087(12)$ & $0.20889(8)$ & $0.0138(3)$ & 1 & $0.4642(2)$ & $0.34976(12)$ & $0.20771(12)$ & $0.0038(4)$ \\
\hline O5 & 1 & $0.79157(19)$ & $0.44857(14)$ & $0.21541(9)$ & $0.0200(3)$ & 1 & $0.7920(2)$ & $0.44738(13)$ & $0.21481(13)$ & $0.0046(4)$ \\
\hline O6 & 1 & $0.0623(2)$ & $0.29066(16)$ & $0.24061(11)$ & $0.0293(4)$ & 1 & $0.0648(2)$ & $0.28819(15)$ & $0.24073(14)$ & $0.0062(4)$ \\
\hline $\mathrm{O} 7$ & 1 & $0.4154(2)$ & $0.70621(16)$ & $-0.00985(10)$ & $0.0301(4)$ & 1 & $0.4169(3)$ & $0.70779(14)$ & $-0.01111(14)$ & $0.0074(5)$ \\
\hline $\mathrm{O} 8$ & 1 & $0.2249(3)$ & $0.53337(18)$ & $0.43187(11)$ & $0.0338(4)$ & 1 & $0.2223(3)$ & $0.53220(17)$ & $0.43146(15)$ & $0.0105(5)$ \\
\hline O9 & 1 & $0.5654(2)$ & $0.27258(13)$ & $0.36300(9)$ & $0.0188(3)$ & 1 & $0.5643(2)$ & $0.27324(13)$ & $0.36308(13)$ & $0.0050(4)$ \\
\hline $\mathrm{O} 10$ & 1 & $-0.0389(2)$ & $0.56220(18)$ & $0.08468(11)$ & $0.0311(4)$ & 1 & $-0.0380(3)$ & $0.55883(16)$ & $0.08588(15)$ & $0.0080(5)$ \\
\hline $\mathrm{O} 11$ & 1 & $0.1674(2)$ & $0.11763(17)$ & $0.07646(11)$ & $0.0294(4)$ & 1 & $0.1662(3)$ & $0.11800(15)$ & $0.07555(14)$ & $0.0074(5)$ \\
\hline B1 & 1 & $0.4469(3)$ & $0.6680(2)$ & $0.07836(14)$ & $0.0173(4)$ & 1 & $0.4480(2)$ & $0.66898(13)$ & $0.07755(14)$ & $0.00330(18)$ \\
\hline B2 & 1 & $0.5532(3)$ & $0.2325(2)$ & $0.26885(13)$ & $0.0137(4)$ & 1 & $0.5530(2)$ & $0.23179(13)$ & $0.26849(13)$ & $0.00260(18)$ \\
\hline B3 & 1 & $0.5736(3)$ & $0.4804(2)$ & $0.19976(14)$ & $0.0141(4)$ & 1 & $0.5738(2)$ & $0.48006(13)$ & $0.19901(13)$ & $0.00272(17)$ \\
\hline B4 & 1 & $0.1323(3)$ & $0.8137(2)$ & $0.25825(15)$ & $0.0184(4)$ & 1 & $0.1300(2)$ & $0.81241(13)$ & $0.25821(13)$ & $0.00304(18)$ \\
\hline H1 & 1 & $0.264(4)$ & $0.100(4)$ & $0.1327(16)$ & $0.072(10)$ & 1 & $0.2679(5)$ & $0.1025(4)$ & $0.1359(3)$ & $0.0207(10)$ \\
\hline $\mathrm{H} 2$ & 1 & $0.106(4)$ & $0.1942(16)$ & $0.2510(19)$ & $0.056(9)$ & 1 & $0.1110(6)$ & $0.1887(4)$ & $0.2510(3)$ & $0.0202(8)$ \\
\hline H3 & 1 & $0.048(4)$ & $0.622(3)$ & $0.1249(19)$ & $0.067(10)$ & 1 & $0.0591(5)$ & $0.6211(4)$ & $0.1296(3)$ & $0.0195(9)$ \\
\hline H4 & 1 & $0.431(5)$ & $0.626(2)$ & $-0.0447(19)$ & $0.072(10)$ & 1 & $0.4388(6)$ & $0.6245(4)$ & $-0.0462(3)$ & $0.0195(9)$ \\
\hline H5 & 1 & $-0.109(4)$ & $0.523(3)$ & $0.120(2)$ & $0.071(10)$ & 1 & $-0.1151(7)$ & $0.5161(5)$ & $0.1215(3)$ & $0.0247(10)$ \\
\hline H6 & 1 & $0.293(5)$ & $0.620(3)$ & $0.454(2)$ & $0.088(12)$ & 1 & $0.2962(6)$ & $0.6219(4)$ & $0.4549(3)$ & $0.0214(8)$ \\
\hline H71 & $0.40(3)$ & $0.197(10)$ & $0.058(6)$ & $0.033(4)$ & $0.046(8)$ & $0.361(14)$ & $0.2060(18)$ & $0.0590(12)$ & $0.0305(11)$ & $0.023(3)$ \\
\hline H72 & $0.60(3)$ & $0.252(7)$ & $0.478(4)$ & $0.485(2)$ & $0.046(8)$ & $0.639(14)$ & $0.2305(10)$ & $0.4714(6)$ & $0.4858(6)$ & $0.0192(17)$ \\
\hline H81 & $0.60(3)$ & $0.048(5)$ & $0.082(5)$ & $0.081(3)$ & $0.046(8)$ & $0.639(14)$ & $0.0370(9)$ & $0.0838(7)$ & $0.0774(5)$ & $0.0208(14)$ \\
\hline H82 & $0.40(3)$ & $0.092(5)$ & $0.568(7)$ & $0.418(5)$ & $0.046(8)$ & $0.361(14)$ & $0.0729(19)$ & $0.5631(12)$ & $0.4193(9)$ & $0.024(2)$ \\
\hline
\end{tabular}


716

717

718

719

720

721

722

723

724

725

726

727

728

729

730

731

732

733

734

735

736

737

738

739

740

741

742

743

744
Table 6 (deposited $)$. Refined displacement parameters $\left(\AA^{2}\right)$ of kernite in the expression: $2 \pi^{2}\left[\left(h a^{*}\right)^{2} U_{11}+\ldots+2 h k a^{*} b^{*} U_{12}+\ldots+2 k l b^{*} c^{*} U_{23}\right]$, based on the X-ray refinement at 293 and neutron structure refinement at $20 \mathrm{~K}$.

\begin{tabular}{l|llllll}
$\boldsymbol{T}=293 \boldsymbol{K}$ & $U_{11}$ & $U_{22}$ & $U_{33}$ & $U_{23}$ & $U_{13}$ & $U_{12}$ \\
\hline Na1 & $0.0299(5)$ & $0.0193(4)$ & $0.0302(5)$ & $0.0008(3)$ & $0.0177(4)$ & $0.0011(3)$ \\
Na2 & $0.0352(5)$ & $0.0245(5)$ & $0.0360(5)$ & $0.0007(4)$ & $-0.0027(4)$ & $-0.0016(4)$ \\
O1 & $0.0291(7)$ & $0.0128(6)$ & $0.0134(6)$ & $0.0002(5)$ & $0.0078(5)$ & $0.0018(5)$ \\
O2 & $0.0222(7)$ & $0.0105(6)$ & $0.0136(6)$ & $-0.0005(5)$ & $0.0048(5)$ & $0.0020(5)$ \\
O3 & $0.0171(7)$ & $0.0162(6)$ & $0.0249(7)$ & $-0.0048(5)$ & $0.0078(5)$ & $-0.0035(5)$ \\
O4 & $0.0146(6)$ & $0.0103(6)$ & $0.0165(6)$ & $0.0013(5)$ & $0.0052(5)$ & $0.0007(4)$ \\
O5 & $0.0174(6)$ & $0.0165(6)$ & $0.0288(7)$ & $0.0020(5)$ & $0.0112(5)$ & $-0.0001(5)$ \\
O6 & $0.0191(7)$ & $0.0249(8)$ & $0.0462(9)$ & $0.0009(6)$ & $0.0138(6)$ & $0.0025(6)$ \\
O7 & $0.0527(8)$ & $0.0212(7)$ & $0.0172(6)$ & $0.0021(5)$ & $0.0126(6)$ & $0.0074(6)$ \\
O8 & $0.0398(8)$ & $0.0335(8)$ & $0.0306(7)$ & $-0.0049(6)$ & $0.0150(6)$ & $-0.0050(6)$ \\
O9 & $0.0286(7)$ & $0.0131(6)$ & $0.0148(6)$ & $-0.0013(5)$ & $0.0073(5)$ & $-0.0028(5)$ \\
O10 & $0.0331(8)$ & $0.0358(8)$ & $0.0249(8)$ & $-0.0046(7)$ & $0.0103(7)$ & $-0.0087(7)$ \\
O11 & $0.0310(7)$ & $0.0292(7)$ & $0.0248(7)$ & $-0.0015(6)$ & $0.0048(6)$ & $-0.0006(6)$ \\
B1 & $0.0216(11)$ & $0.0154(10)$ & $0.0152(10)$ & $0.0008(8)$ & $0.0064(8)$ & $0.0006(8)$ \\
B2 & $0.0167(10)$ & $0.0112(9)$ & $0.0133(10)$ & $0.0007(7)$ & $0.0051(8)$ & $0.0002(7)$ \\
B3 & $0.0177(10)$ & $0.0113(9)$ & $0.0148(10)$ & $0.0002(7)$ & $0.0073(8)$ & $0.0005(7)$ \\
B4 & $0.0181(10)$ & $0.0190(10)$ & $0.0191(10)$ & $0.0016(8)$ & $0.0071(8)$ & $-0.0004(8)$ \\
\hline Note: All the H sites were modelled isotropically in the X-ray structure refinement at 293 K \\
\hline \multicolumn{7}{c}{}
\end{tabular}




\begin{tabular}{|c|c|c|c|c|c|c|}
\hline$T=20 K$ & $U_{11}$ & $U_{22}$ & $U_{33}$ & $U_{23}$ & $U_{13}$ & $U_{12}$ \\
\hline $\mathrm{Nal}$ & $0.0050(9)$ & $0.0059(6)$ & $0.0090(15)$ & $0.0005(7)$ & $0.0019(10)$ & $0.0004(6)$ \\
\hline $\mathrm{Na} 2$ & $0.0055(9)$ & $0.0066(6)$ & $0.0084(15)$ & $0.0009(7)$ & $0.0005(10)$ & $-0.0010(6)$ \\
\hline $\mathrm{O} 1$ & $0.0054(5)$ & $0.0035(3)$ & $0.0052(8)$ & $-0.0004(4)$ & $0.0003(6)$ & $0.0009(4)$ \\
\hline $\mathrm{O} 2$ & $0.0026(5)$ & $0.0038(3)$ & $0.0049(7)$ & $-0.0002(4)$ & $0.0013(5)$ & $0.0005(3)$ \\
\hline $\mathrm{O} 3$ & $0.0019(4)$ & $0.0047(3)$ & $0.0069(7)$ & $-0.0010(4)$ & $0.0012(5)$ & $-0.0006(3)$ \\
\hline $\mathrm{O} 4$ & $0.0016(5)$ & $0.0037(3)$ & $0.0055(7)$ & $0.0008(3)$ & $0.0002(5)$ & $-0.0003(3)$ \\
\hline O5 & $0.0023(4)$ & $0.0049(3)$ & $0.0065(7)$ & $0.0005(4)$ & $0.0014(5)$ & $0.0005(3)$ \\
\hline O6 & $0.0028(5)$ & $0.0069(4)$ & $0.0094(7)$ & $0.0000(4)$ & $0.0026(5)$ & $0.0011(4)$ \\
\hline $\mathrm{O} 7$ & $0.0098(6)$ & $0.0056(4)$ & $0.0065(9)$ & $0.0006(4)$ & $0.0021(6)$ & $0.0017(4)$ \\
\hline O8 & $0.0084(7)$ & $0.0106(5)$ & $0.0123(11)$ & $-0.0035(6)$ & $0.0030(7)$ & $-0.0029(5)$ \\
\hline O9 & $0.0040(5)$ & $0.0044(3)$ & $0.0062(9)$ & $-0.0007(4)$ & $0.0011(6)$ & $-0.0007(4)$ \\
\hline $\mathrm{O} 10$ & $0.0053(6)$ & $0.0083(4)$ & $0.0093(10)$ & $-0.0009(5)$ & $0.0008(7)$ & $-0.0006(4)$ \\
\hline O11 & $0.0043(6)$ & $0.0075(4)$ & $0.0094(10)$ & $0.0000(5)$ & $0.0009(6)$ & $-0.0002(4)$ \\
\hline $\mathrm{H} 1$ & $0.0159(14)$ & $0.0222(12)$ & $0.020(2)$ & $0.0008(12)$ & $0.0010(13)$ & $-0.0002(11)$ \\
\hline $\mathrm{H} 2$ & $0.0178(12)$ & $0.0159(9)$ & $0.0264(16)$ & $0.0027(10)$ & $0.0063(11)$ & $0.0062(9)$ \\
\hline H3 & $0.0150(12)$ & $0.0202(11)$ & $0.0232(18)$ & $-0.0044(11)$ & $0.0059(12)$ & $-0.0085(10)$ \\
\hline $\mathrm{H} 4$ & $0.0224(15)$ & $0.0163(10)$ & $0.020(2)$ & $-0.0008(11)$ & $0.0068(14)$ & $-0.0002(11)$ \\
\hline H5 & $0.0213(16)$ & $0.0244(14)$ & $0.029(2)$ & $0.0010(15)$ & $0.0095(16)$ & $-0.0038(14)$ \\
\hline H6 & $0.0214(13)$ & $0.0185(10)$ & $0.0235(16)$ & $-0.0045(11)$ & $0.0064(11)$ & $-0.0083(10)$ \\
\hline H71 & $0.018(4)$ & $0.022(3)$ & $0.029(7)$ & $-0.005(4)$ & $0.008(4)$ & $0.000(3)$ \\
\hline $\mathrm{H} 72$ & $0.021(2)$ & $0.0195(17)$ & $0.016(3)$ & $0.0053(18)$ & $0.005(2)$ & $0.0008(17)$ \\
\hline H81 & $0.0170(19)$ & $0.0234(16)$ & $0.022(2)$ & $-0.0018(15)$ & $0.0058(14)$ & $-0.0013(13)$ \\
\hline H82 & $0.023(3)$ & $0.024(2)$ & $0.024(3)$ & $0.0001(10)$ & $0.0078(11)$ & $-0.0002(10)$ \\
\hline
\end{tabular}


Table 7. Relevant bond distances $(\AA)$ and angles $\left(^{\circ}\right)$ based on the X-ray refinement at $293 \mathrm{~K}$ and neutron structure refinement at $20 \mathrm{~K}$.

\begin{tabular}{|c|c|c|c|c|c|}
\hline \multicolumn{2}{|l|}{$\begin{array}{l}X \text {-ray } \\
T=293 \mathrm{~K}\end{array}$} & \multirow[b]{2}{*}{ O11-H1 } & \multirow[b]{2}{*}{$0.94(2)$} & \multirow[b]{2}{*}{ O8-H72 } & \multirow[b]{2}{*}{$0.93(4)$} \\
\hline Na1-O8 & $2.2835(18)$ & & & & \\
\hline Na1-O6 & $2.3879(17)$ & O11-H1* & 0.97 & $\mathrm{O} 8-\mathrm{H} 72 *$ & 0.96 \\
\hline Na1-O4 & $2.3918(14)$ & $\mathrm{O} 11 \cdots \mathrm{O} 2$ & $2.669(2)$ & $\mathrm{O} 8 \cdots \mathrm{O} 11$ & $2.787(3)$ \\
\hline Na1-O9 & $2.4095(15)$ & $\mathrm{H} 1 \cdots \mathrm{O} 2$ & $1.74(2)$ & $\mathrm{H} 72 \cdots \mathrm{O} 11$ & $1.93(4)$ \\
\hline $\mathrm{Na} 1-\mathrm{O} 2$ & $2.4226(14)$ & $\mathrm{O} 11-\mathrm{H} 1 \cdots \mathrm{O} 2$ & $170(2)$ & $\mathrm{O} 8-\mathrm{H} 72 \cdots \mathrm{O} 11$ & $152(3)$ \\
\hline \multirow{2}{*}{ Na1-O3 } & $2.5058(15)$ & & & & \\
\hline & & O11-H71 & $0.94(7)$ & O8-H82 & $0.94(4)$ \\
\hline $\mathrm{Na} 2-\mathrm{O} 11$ & $2.2790(17)$ & O11-H71* & 0.97 & O8-H82* & 0.97 \\
\hline $\mathrm{Na} 2-\mathrm{O} 4$ & $2.3880(15)$ & $\mathrm{O} 11 \cdots \mathrm{O} 8$ & $2.787(3)$ & $\mathrm{O} 8 \cdots \mathrm{O} 11$ & $2.814(3)$ \\
\hline $\mathrm{Na} 2-\mathrm{O} 10$ & $2.4274(18)$ & $\mathrm{H} 71 \cdots \mathrm{O} 8$ & $1.86(6)$ & $\mathrm{H} 82 \cdots \mathrm{O} 11$ & $1.90(5)$ \\
\hline Na2-O10' & $2.4287(19)$ & $\mathrm{O} 11-\mathrm{H} 71 \cdots \mathrm{O} 8$ & $169(5)$ & O8-H82 $\cdots \mathrm{O} 11$ & $163(4)$ \\
\hline $\mathrm{Na} 2-\mathrm{O} 1$ & $2.4791(16)$ & & & & \\
\hline \multirow[t]{2}{*}{$\mathrm{Na} 2-\mathrm{O} 6$} & $3.099(4)$ & O11-H81 & $0.92(4)$ & H6-O8-H72 & $102(3)$ \\
\hline & & O11-H81* & 0.95 & H6-O8-H82 & $100(4)$ \\
\hline B1-O1 & $1.363(2)$ & $\mathrm{O} 11 \cdots \mathrm{O} 8$ & $2.814(3)$ & & \\
\hline B1-O7 & $1.370(2)$ & $\mathrm{H} 81 \cdots \mathrm{O} 8$ & $1.91(4)$ & & \\
\hline B1-O9 & $1.346(2)$ & $\mathrm{O} 11-\mathrm{H} 81 \cdots \mathrm{O} 8$ & $168(3)$ & & \\
\hline B2-O2 & $1.443(2)$ & H1-O11-H71 & $108(5)$ & & \\
\hline B2-O4 & $1.434(2)$ & H1-O11-H81 & $106(3)$ & & \\
\hline B2-O9 & $1.493(2)$ & & & & \\
\hline \multirow{2}{*}{$\mathrm{B} 2-\mathrm{O} 3$} & $1.520(2)$ & O6-H2 & $0.93(2)$ & & \\
\hline & & O6-H2* & 0.96 & & \\
\hline B3-O1 & $1.497(2)$ & $\mathrm{O} 6 \cdots \mathrm{O} 5$ & $3.292(2)$ & & \\
\hline B3-O2 & $1.450(2)$ & $\mathrm{H} 2 \cdots \mathrm{O} 5$ & $2.36(2)$ & & \\
\hline B3-O4 & $1.438(2)$ & $\mathrm{O} 6-\mathrm{H} 2 \cdots \mathrm{O} 5$ & $177(1)$ & & \\
\hline \multirow[t]{2}{*}{ B3-O5 } & $1.493(2)$ & & & & \\
\hline & & O10-H3 & $0.91(3)$ & & \\
\hline B4-O3 & $1.352(2)$ & O10-H3* & 0.94 & & \\
\hline B4-O5 & $1.353(2)$ & $\mathrm{O} 10 \cdots \mathrm{O} 3$ & $2.790(2)$ & & \\
\hline \multirow{2}{*}{ B4-O6 } & $1.384(3)$ & $\mathrm{H} 3 \cdots \mathrm{O} 3$ & $1.91(3)$ & & \\
\hline & & $\mathrm{O} 10-\mathrm{H} 3 \cdots \mathrm{O} 3$ & $164(3)$ & & \\
\hline O1-B1-O9 & $122.8(2)$ & O7-H4 & $0.94(3)$ & & \\
\hline O7-B1-O9 & $118.7(2)$ & O7-H4* & 0.97 & & \\
\hline \multirow[t]{2}{*}{$\mathrm{O} 1-\mathrm{B} 1-\mathrm{O} 7$} & $118.5(2)$ & $\mathrm{O} 7 \cdots \mathrm{O} 1$ & $2.773(2)$ & & \\
\hline & & $\mathrm{H} 4 \cdots \mathrm{O} 1$ & $1.84(3)$ & & \\
\hline $\mathrm{O} 4-\mathrm{B} 2-\mathrm{O} 2$ & $111.24(14)$ & $\mathrm{O} 7-\mathrm{H} 4 \cdots \mathrm{O} 1$ & $169(2)$ & & \\
\hline O4-B2-O9 & 109.61(14) & & & & \\
\hline O2-B2-O9 & $110.91(14)$ & O10-H5 & $0.92(4)$ & & \\
\hline O4-B2-O3 & $109.58(14)$ & O10-H5* & 0.95 & & \\
\hline $\mathrm{O} 2-\mathrm{B} 2-\mathrm{O} 3$ & $107.95(14)$ & $\mathrm{O} 10 \cdots \mathrm{O} 5$ & $2.869(2)$ & & \\
\hline \multirow[t]{2}{*}{$\mathrm{O} 9-\mathrm{B} 2-\mathrm{O} 3$} & $107.46(14)$ & $\mathrm{H} 5 \cdots \mathrm{O} 5$ & $1.96(4)$ & & \\
\hline & & $\mathrm{O} 10-\mathrm{H} 5 \cdots \mathrm{O} 5$ & $168(3)$ & & \\
\hline $\mathrm{O} 4-\mathrm{B} 3-\mathrm{O} 2$ & $113.89(15)$ & & & & \\
\hline O4-B3-O5 & $111.57(14)$ & H3-O10-H5 & 101(3) & & \\
\hline O2-B3-O5 & $108.45(15)$ & & & & \\
\hline O4-B3-O1 & $105.85(14)$ & O8-H6 & $0.93(3)$ & & \\
\hline O2-B3-O1 & $110.79(14)$ & O8-H6* & 0.96 & & \\
\hline \multirow[t]{2}{*}{ O5-B3-O1 } & $106.00(14)$ & $\mathrm{O} 8 \cdots \mathrm{O} 7$ & $2.736(2)$ & & \\
\hline & & $\mathrm{H} 6 \cdots \mathrm{O} 7$ & $1.81(3)$ & & \\
\hline O3-B4-O5 & $124.41(17)$ & $\mathrm{O} 8-\mathrm{H} 6 \cdots \mathrm{O} 7$ & $176(3)$ & & \\
\hline O3-B4-O6 & $120.31(17)$ & & & & \\
\hline O5-B4-O6 & $115.28(17)$ & & & & \\
\hline
\end{tabular}




\begin{tabular}{|c|c|c|c|c|c|}
\hline \multicolumn{2}{|l|}{$\begin{array}{l}\text { Neutron } \\
T=20 \mathrm{~K}\end{array}$} & \multirow[b]{2}{*}{ O11-H1 } & \multirow[b]{2}{*}{$0.988(4)$} & \multirow[b]{2}{*}{ O8-H72 } & \multirow[b]{2}{*}{$1.000(8)$} \\
\hline Na1-O8 & $2.294(5)$ & & & & \\
\hline Na1-O6 & $2.377(2)$ & $\mathrm{O} 11-\mathrm{H} 1 *$ & 1.003 & O8-H72* & 1.014 \\
\hline $\mathrm{Na1-O4}$ & $2.395(4)$ & $\mathrm{O} 11 \cdots \mathrm{O} 2$ & $2.663(3)$ & $\mathrm{O} 8 \cdots \mathrm{O} 11$ & $2.769(3)$ \\
\hline Na1-O9 & $2.393(2)$ & $\mathrm{H} 1 \cdots \mathrm{O} 2$ & 1.68084) & $\mathrm{H} 72 \cdots \mathrm{O} 11$ & $1.800(9)$ \\
\hline $\mathrm{Na} 1-\mathrm{O} 2$ & $2.422(4)$ & $\mathrm{O} 11-\mathrm{H} 1 \cdots \mathrm{O} 2$ & $173.0(4)$ & $\mathrm{O} 8-\mathrm{H} 72 \cdots \mathrm{O} 11$ & $162.2(7)$ \\
\hline \multirow[t]{2}{*}{$\mathrm{Na} 1-\mathrm{O} 3$} & 2.493(3) & & & & \\
\hline & & O11-H71 & $0.995(17)$ & O8-H82 & $1.038(13)$ \\
\hline Na2-O11 & $2.291(3)$ & O11-H71* & 1.012 & O8-H82* & 1.051 \\
\hline $\mathrm{Na} 2-\mathrm{O} 4$ & $2.382(3)$ & $\mathrm{O} 11 \cdots \mathrm{O} 8$ & $2.769(3)$ & $\mathrm{O} 8 \cdots \mathrm{O} 11$ & $2.796(3)$ \\
\hline $\mathrm{Na} 2-\mathrm{O} 10$ & 2.411(3) & $\mathrm{H} 71 \cdots \mathrm{O} 8$ & $1.792(17)$ & $\mathrm{H} 82 \cdots \mathrm{O} 11$ & $1.773(14)$ \\
\hline Na2-O10' & $2.411(4)$ & $\mathrm{O} 11-\mathrm{H} 71 \cdots \mathrm{O} 8$ & $167(1)$ & $\mathrm{O} 8-\mathrm{H} 82 \cdots \mathrm{O} 11$ & $168(1)$ \\
\hline $\mathrm{Na} 2-\mathrm{O} 1$ & $2.453(3)$ & & & & \\
\hline \multirow[t]{2}{*}{$\mathrm{Na} 2-\mathrm{O} 6$} & $3.134(21)$ & O11-H81 & $0.966(7)$ & H6-O8-H72 & $105.8(5)$ \\
\hline & & O11-H81* & 0.981 & H6-O8-H82 & $102.7(7)$ \\
\hline B1-O1 & $1.3685(17)$ & $\mathrm{O} 11 \cdots \mathrm{O} 8$ & $2.796(3)$ & & \\
\hline B1-O7 & $1.375(3)$ & $\mathrm{H} 81 \cdots \mathrm{O} 8$ & $1.835(7)$ & & \\
\hline B1-O9 & $1.350(3)$ & $\mathrm{O} 11-\mathrm{H} 81 \cdots \mathrm{O} 8$ & $173.1(6)$ & & \\
\hline B2-O2 & $1.4457(16)$ & H1-O11-H71 & $108.4(7)$ & & \\
\hline B2-O4 & $1.4353(18)$ & H1-O11-H81 & $108.3(5)$ & & \\
\hline B2-O9 & $1.501(3)$ & & & & \\
\hline \multirow[t]{2}{*}{ B2-O3 } & $1.523(3)$ & O6-H2 & $0.960(4)$ & & \\
\hline & & O6-H2* & 0.978 & & \\
\hline B3-O1 & $1.496(3)$ & $\mathrm{O} 6 \cdots \mathrm{O} 5$ & $3.273(2)$ & & \\
\hline B3-O2 & $1.454(3)$ & $\mathrm{H} 2 \cdots \mathrm{O} 5$ & $2.316(4)$ & & \\
\hline B3-O4 & $1.445(2)$ & $\mathrm{O} 6-\mathrm{H} 2 \cdots \mathrm{O} 5$ & $174.9(3)$ & & \\
\hline \multirow[t]{2}{*}{ B3-O5 } & $1.494(3)$ & & & & \\
\hline & & O10-H3 & $0.974(4)$ & & \\
\hline B4-O3 & $1.363(3)$ & O10-H3* & 0.988 & & \\
\hline B4-O5 & $1.3577(17)$ & $\mathrm{O} 10 \cdots \mathrm{O} 3$ & $2.772(2)$ & & \\
\hline \multirow[t]{2}{*}{ B4-O6 } & $1.385(3)$ & $\mathrm{H} 3 \cdots \mathrm{O} 3$ & $1.818(4)$ & & \\
\hline & & $\mathrm{O} 10-\mathrm{H} 3 \cdots \mathrm{O} 3$ & $165.7(4)$ & & \\
\hline O1-B1-O9 & $122.5(2)$ & O7-H4 & $0.977(4)$ & & \\
\hline O7-B1-O9 & $118.97(13)$ & O7-H4* & 0.990 & & \\
\hline \multirow[t]{2}{*}{ O1-B1-O7 } & $118.56(18)$ & $\mathrm{O} 7 \cdots \mathrm{O} 1$ & $2.759(3)$ & & \\
\hline & & $\mathrm{H} 4 \cdots \mathrm{O} 1$ & $1.787(4)$ & & \\
\hline O4-B2-O2 & $110.93(11)$ & $\mathrm{O} 7-\mathrm{H} 4 \cdots \mathrm{O} 1$ & $172.4(3)$ & & \\
\hline O4-B2-O9 & $109.47(14)$ & & & & \\
\hline O2-B2-O9 & $110.90(18)$ & O10-H5 & $0.974(6)$ & & \\
\hline O4-B2-O3 & 109.79(18) & O10-H5* & 0.994 & & \\
\hline $\mathrm{O} 2-\mathrm{B} 2-\mathrm{O} 3$ & 107.92(13) & $\mathrm{O} 10 \cdots \mathrm{O} 5$ & $2.840(3)$ & & \\
\hline \multirow[t]{2}{*}{ O9-B2-O3 } & $107.76(12)$ & $\mathrm{H} 5 \cdots \mathrm{O} 5$ & $1.885(6)$ & & \\
\hline & & $\mathrm{O} 10-\mathrm{H} 5 \cdots \mathrm{O} 5$ & $165.8(5)$ & & \\
\hline O4-B3-O2 & $113.7(2)$ & & & & \\
\hline O4-B3-O5 & $111.38(11)$ & H3-O10-H5 & $102.9(5)$ & & \\
\hline O2-B3-O5 & $108.49(11)$ & & & & \\
\hline O4-B3-O1 & $105.57(11)$ & O8-H6 & $0.974(4)$ & & \\
\hline O2-B3-O1 & $111.29(11)$ & O8-H6* & 0.988 & & \\
\hline \multirow[t]{2}{*}{ O5-B3-O1 } & $106.2(2)$ & $08 \cdots \mathrm{O} 7$ & $2.737(2)$ & & \\
\hline & & $\mathrm{H} 6 \cdots \mathrm{O} 7$ & $1.766(4)$ & & \\
\hline O3-B4-O5 & $123.67(19)$ & $\mathrm{O} 8-\mathrm{H} 6 \cdots \mathrm{O} 7$ & $175.0(4)$ & & \\
\hline O3-B4-O6 & $116.01(17)$ & & & & \\
\hline O5-B4-O6 & $120.32(12)$ & & & & \\
\hline
\end{tabular}


Figure 1. The crystal structure of kernite viewed down [010] (left side), along with the infinite chains of 3-fold rings (3B: $\Delta+2 \mathrm{~T}$ units) running along [010] (right side), based on the neutron structure refinement of this study (intensity data collected at $20 \mathrm{~K}$ ). Displacement ellipsoid probability factor: $70 \%$.
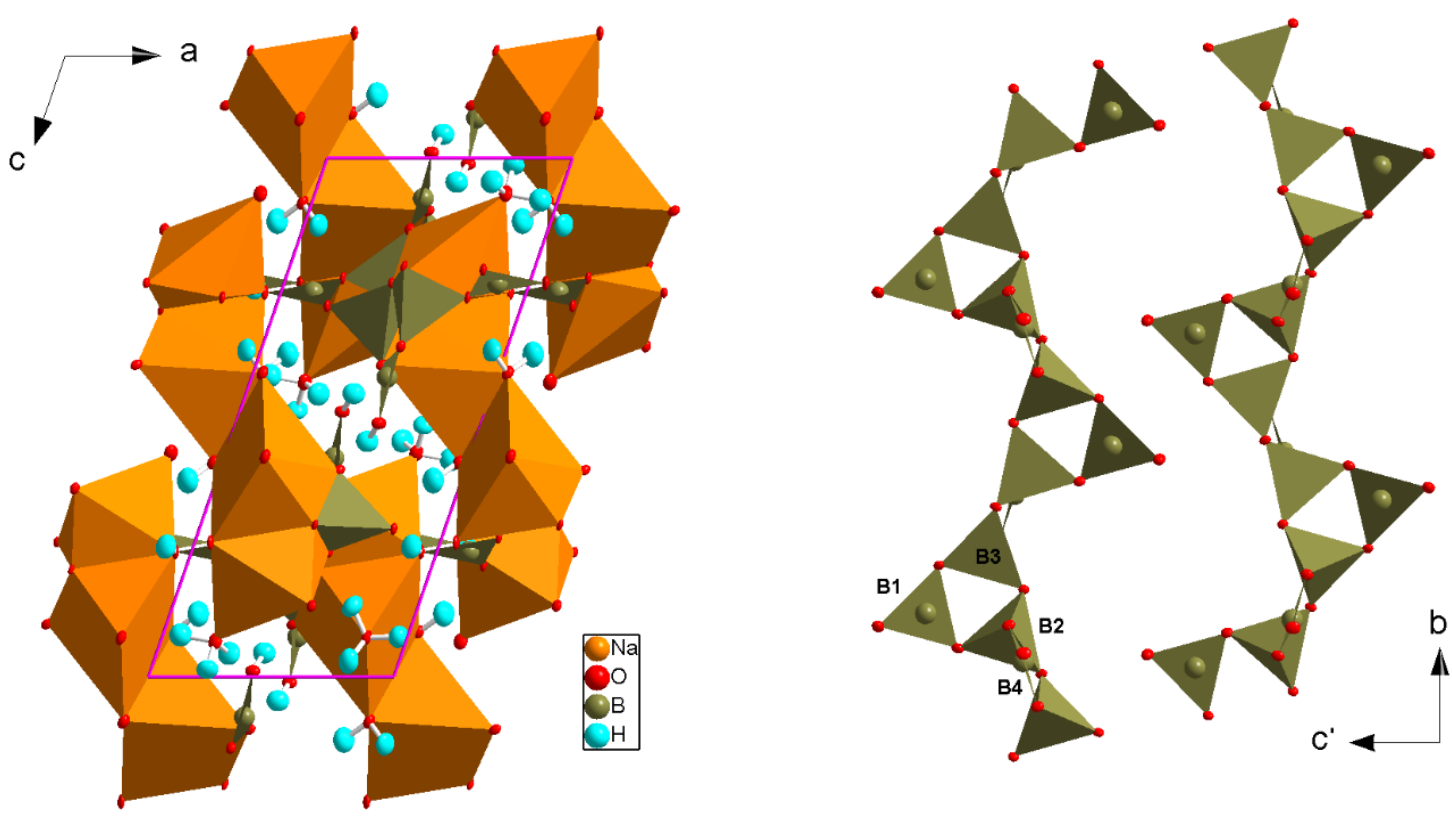
Figure 2. Positional disorder of the $\mathrm{H}$ sites in the structure of kernite, based on the neutron structure refinement of this study (intensity data collected at $20 \mathrm{~K}$ ). The mutually exclusive configurations are: $(\mathrm{H} 6-\mathrm{O} 8-\mathrm{H} 82+\mathrm{H} 1-\mathrm{O} 11-\mathrm{H} 71)$ and $(\mathrm{H} 6-\mathrm{O} 8-\mathrm{H} 72+\mathrm{H} 1-\mathrm{O} 11-\mathrm{H} 81)$; s.o.f.(H6) $=1$, s.o.f.(H1) $=1$, [s.o.f. $(\mathrm{H} 72)+$ s.o.f. $(\mathrm{H} 82)]=1$, [s.o.f. $(\mathrm{H} 71)+$ s.o.f. $(\mathrm{H} 81)]=1$. Displacement ellipsoid probability factor: $70 \%$.

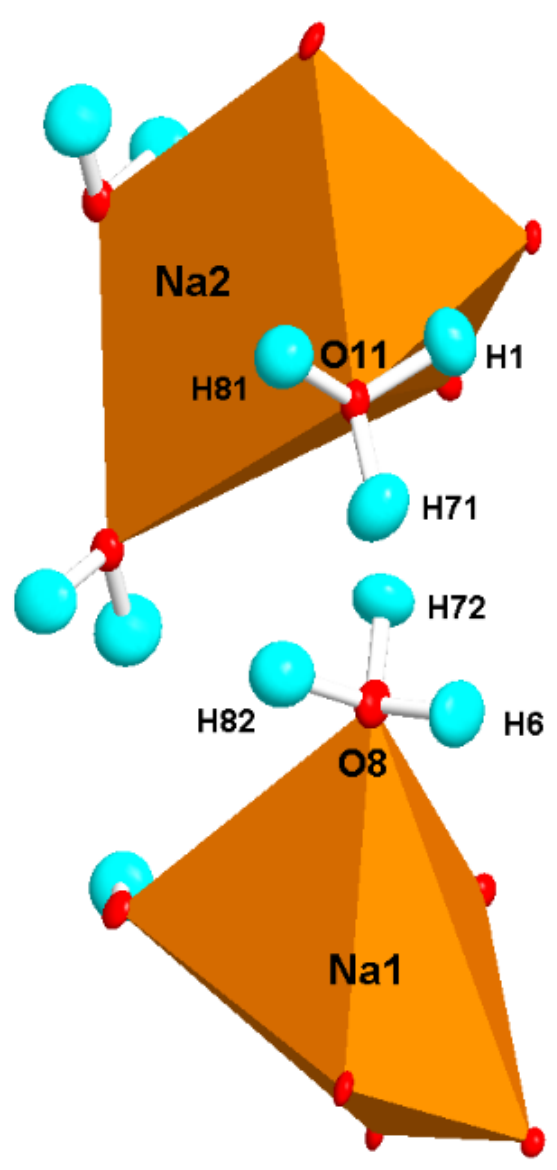


Figure 3. Section of the nuclear density function, corresponding to the $(0.1,0.5,0.6)$ plane (which contains $\mathrm{O} 8, \mathrm{O} 11$ and symmetry-related $\mathrm{H}_{2} \mathrm{O}$ molecules), calculated using the maximum-entropy method applied to the neutron intensity data collected at $20 \mathrm{~K}$. A grid of $256 \times 256 \times 256$ voxels was used to obtain a detailed density map. Further details are given in the text. Graphical representation by VESTA. Colour bar: maxima at the top, minima at the bottom of the nuclear density. Atom labels showing a prime involve that those atoms are generated by application of a symmetry operator.

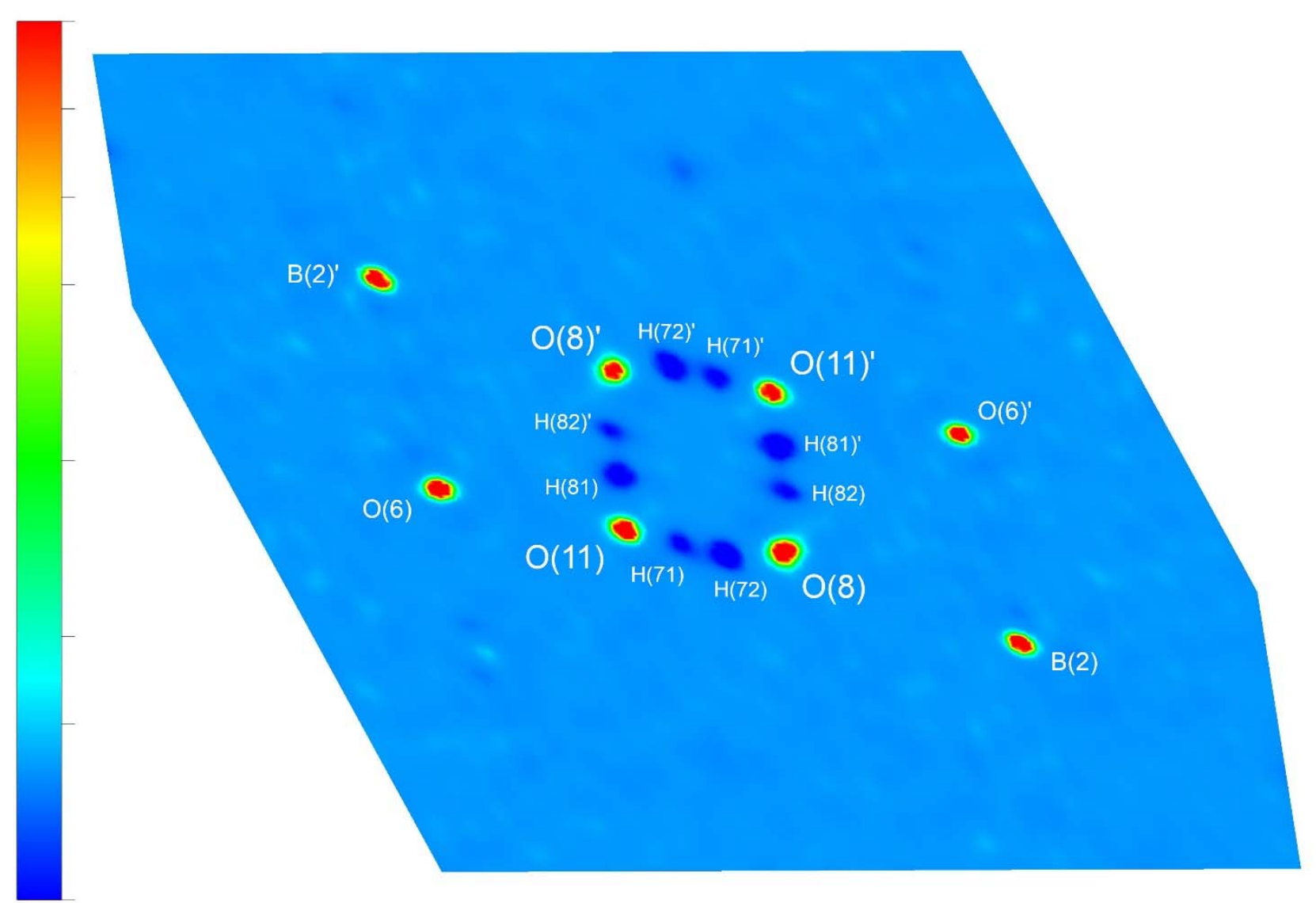


Figure 4. The complex H-bonding network into the crystal structure of kernite, based on the neutron structure refinement (data collected at $20 \mathrm{~K}$ ). Details in Table 7. Displacement ellipsoid probability factor: $70 \%$.

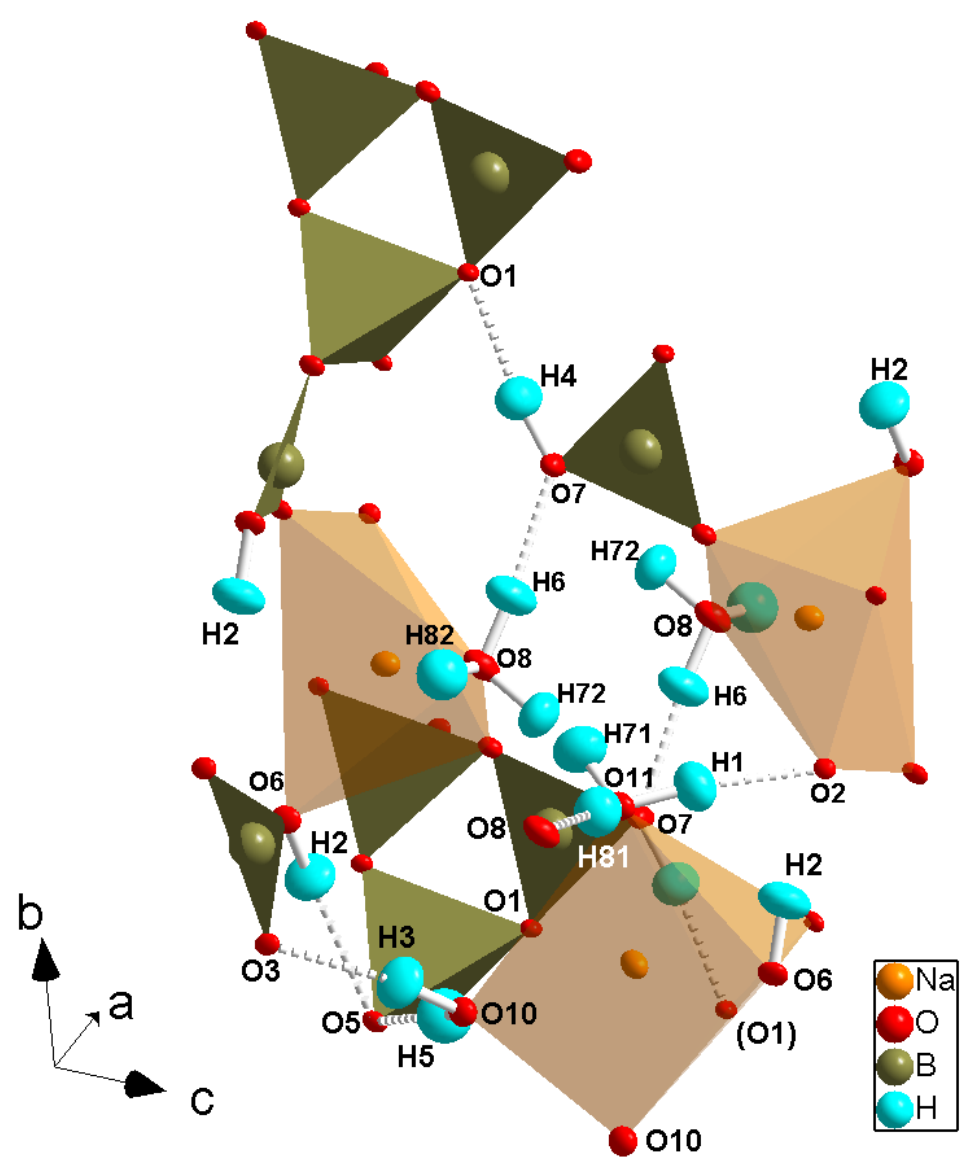

